\title{
Systematic revision of the limestone karst-restricted land snail genus Aenigmatoconcha (Eupulmonata: Helicarionidae), with description of a new species
}

\author{
Arthit PHOLYOTHA ${ }^{\circledR 1}$, Chirasak SUTCHARIT ${ }^{\circledR 2}$, Piyoros TONGKERD ${ }^{\circledR 3}{ }^{3} \&$ \\ Somsak PANHA $1{ }^{4}, *$ \\ ${ }^{1,2,3}$ Animal Systematics Research Unit, Department of Biology, Faculty of Science, \\ Chulalongkorn University, Bangkok 10330, Thailand. \\ ${ }^{4}$ Academy of Science, The Royal Society of Thailand, Bangkok 10300, Thailand. \\ *Corresponding author: somsak.pan@chula.ac.th \\ ${ }^{1}$ Email: arthitpolyotha@gmail.com \\ 2Email: jirasak4@yahoo.com \\ ${ }^{3}$ Email: piyorose@hotmail.com \\ ${ }^{1}$ https://orcid.org/0000-0001-6677-1164 \\ ${ }^{2}$ https://orcid.org/0000-0001-7670-9540 \\ ${ }^{3} \mathrm{https}: / /$ orcid.org/0000-0001-9221-9293 \\ ${ }^{4} \mathrm{https}$ ://orcid.org/0000-0002-4431-2458 \\ ${ }^{1}$ urn:1sid:zoobank.org:author:6CC9B5FE-6586-4132-8289-102DC14D3844 \\ ${ }^{2}$ urn:1sid:zoobank.org:author:ED1BD3A8-0B41-4062-A575-EEAC278A9D00 \\ ${ }^{3}$ urn:1sid:zoobank.org:author:18575FA7-4812-4D75-8568-24D9E7D90BC6 \\ ${ }^{4}$ urn:lsid:zoobank.org:author:AC935098-D901-4F35-A414-4B0D4FE44E79
}

\begin{abstract}
Thai limestone karsts are known to contain a rich biodiversity of animals, especially terrestrial snails, but still require further intensive exploration to evaluate their biodiversity. To date, only a few studies on the limestone karst-inhabiting land snail genera have been published. The present work focuses on the species diversity and phylogenetic relationships of the limestone karst-restricted land snail genus Aenigmatoconcha from Thailand, based on comparative morphology and molecular evidence. The results yielded three known species (A. clivicola Tumpeesuwan \& Tumpeesuwan, 2017, A. sumonthai Tumpeesuwan \& Tumpeesuwan, 2018, and A. mitis (Pfeiffer, 1863) comb. nov.), plus a new species (A. eunetis Pholyotha \& Panha sp. nov). The phylogenetic analyses of partial fragments of the mitochondrial cytochrome oxidase c subunit I (COI) gene confirmed the monophyly of all recognized species and congruence with the traditional morphology-based species designations. Average uncorrected p-distances of COI sequences between species were 9.7-12.0\% and within species were $0.2-4.2 \%$. This study also provides the re-description of penial sculpture, penial sheath, flagellum, penial caecum, and mantle lobe morphology that were neglected from the type species description. The present discovery of a new species increases the known diversity of Thai land snails and will support the conservation planning to protect karst biodiversity.
\end{abstract}


Keywords. Endemic, Indochina, limestones, COI gene, DNA barcoding.

Pholyotha A., Sutcharit C., Tongkerd P \& Panha S. 2021. Systematic revision of the limestone karst-restricted land snail genus Aenigmatoconcha (Eupulmonata: Helicarionidae), with description of a new species. European Journal of Taxonomy 767: 55-82. https://doi.org/10.5852/ejt.2021.767.1487

\section{Introduction}

Situated in the Indo-Burmese biodiversity hotspot region, Thailand is one of the most bio-diverse countries in mainland Southeast Asia (Myers et al. 2000). The country boasts many unique limestone formations (Naggs et al. 2006; Ridd et al. 2011; Latinne et al. 2013). Thus, Thailand houses many endemic cave-dwelling animals, such as various groups of vertebrates (e.g., Latinne et al. 2013; Pauwels et al. 2014; Sumontha et al. 2017) and invertebrates (e.g., Sedgwick \& Schwendinger 1990; Srisonchai et al. 2018; Likhitrakarn et al. 2020), especially several families of land snails (e.g., Tongkerd et al. 2004; Siriboon et al. 2014; Dumrongrojwattana \& Tanmuangpak 2020; Pholyotha et al. 2020b, 2021; Sutcharit et al. 2020b). Although the recent studies of karst-associated land snail species in Southeast Asia have flourished, the number of new species discovered has increased every year, supporting that the Thai fauna on limestone karsts, especially land snails, still remains mostly unexplored.

Native to Thailand, the helicarionid snail genus Aenigmatoconcha Tumpeesuwan \& Tumpeesuwan, 2017 occurs in limestone karst areas only. The specific characteristics of this genus include a mediumsized and umbilicated shell, radula with spatulate-shaped teeth, and genitalia without a dart apparatus (Tumpeesuwan \& Tumpeesuwan 2017, 2018). Until now, two species have been included in this genus (A. clivicola Tumpeesuwan \& Tumpeesuwan, 2017 from Northeast Thailand, and A. sumonthai Tumpeesuwan \& Tumpeesuwan, 2018 from Southern Thailand). Although Aenigmatoconcha was recently described including its genital and radula features, several other diagnostic characters have never been mentioned for either species. These key characters are important for identification at both the specific and generic levels. Thus, the genitalia and mantle lobe morphology were re-examined in this study. Moreover, as the type localities of the two known Aenigmatoconcha species are distantly separated by approximately $900 \mathrm{~km}$, it is expected that Aenigmatoconcha species may also occur in limestone karts along the Tenasserim Range from North to South Thailand (Naggs et al. 2006; Ridd et al. 2011; Latinne et al. 2013; Gardner et al. 2015).

During a recent intensive field survey throughout Thailand, many helicarionid specimens have been classified as members of Aenigmatoconcha on the basis of their shell morphology and genital anatomy. Some populations shared similarities in shell morphology, but the genitalia tended to differ from congeners and were not identical to any currently described species. Generally, helicarionoid snails tend to have a diverse shell form but conserved reproductive organs and mantle lobes. These conserved characters appear to be systematically informative following integrative taxonomic approaches, such as in the Southeast Asian ariophantids (Pholyotha et al. 2020b, 2021; Sutcharit et al. 2020b) and helicarionids (Páll-Gergely et al. 2016; Sutcharit et al. 2020a), and in the Australian helicarionids (Hyman \& Ponder 2010; Hyman \& Köhler 2018, 2019).

In recent years, the mitochondrial cytochrome c oxidase subunit I (COI) gene has been widely used as a standard barcoding marker to delineate species, for systematic revision, and to investigate phylogenetic relationships in various groups of land snails (i.e., Liew et al. 2009; Hyman \& Ponder 2010; Köhler \& Criscione 2015; Hyman \& Köhler 2018, 2019; Zhang et al. 2020; Siriboon et al. 2020). This study integrates morphological and COI gene data to clarify the species boundaries within the genus Aenigmatoconcha. The aims of this research are to 1) clarify the species boundaries and relationships within the genus, 2) revise the genitalia and mantle lobe morphology of $A$. clivicola and A. sumonthai, 3) re-describe the 
long-overlooked species, A. mitis (Pfeiffer, 1863), and 4) describe a new species based on morphological (living snails, shells, genitalia, and radula) information and COI gene sequence analyses.

\section{Material and methods}

\section{Specimen sampling and morphological studies}

Several limestone and non-limestone areas in Thailand were surveyed. All Aenigmatoconcha specimens were found on limestone areas only (Fig. 1) and were hand-collected. Living snails were euthanized by a two-step method following the AVMA Guidelines for the Euthanasia of Animals (American Veterinary Medical Association 2020) and then fixed in 95\% (v/v) ethanol for morphological and DNA studies.

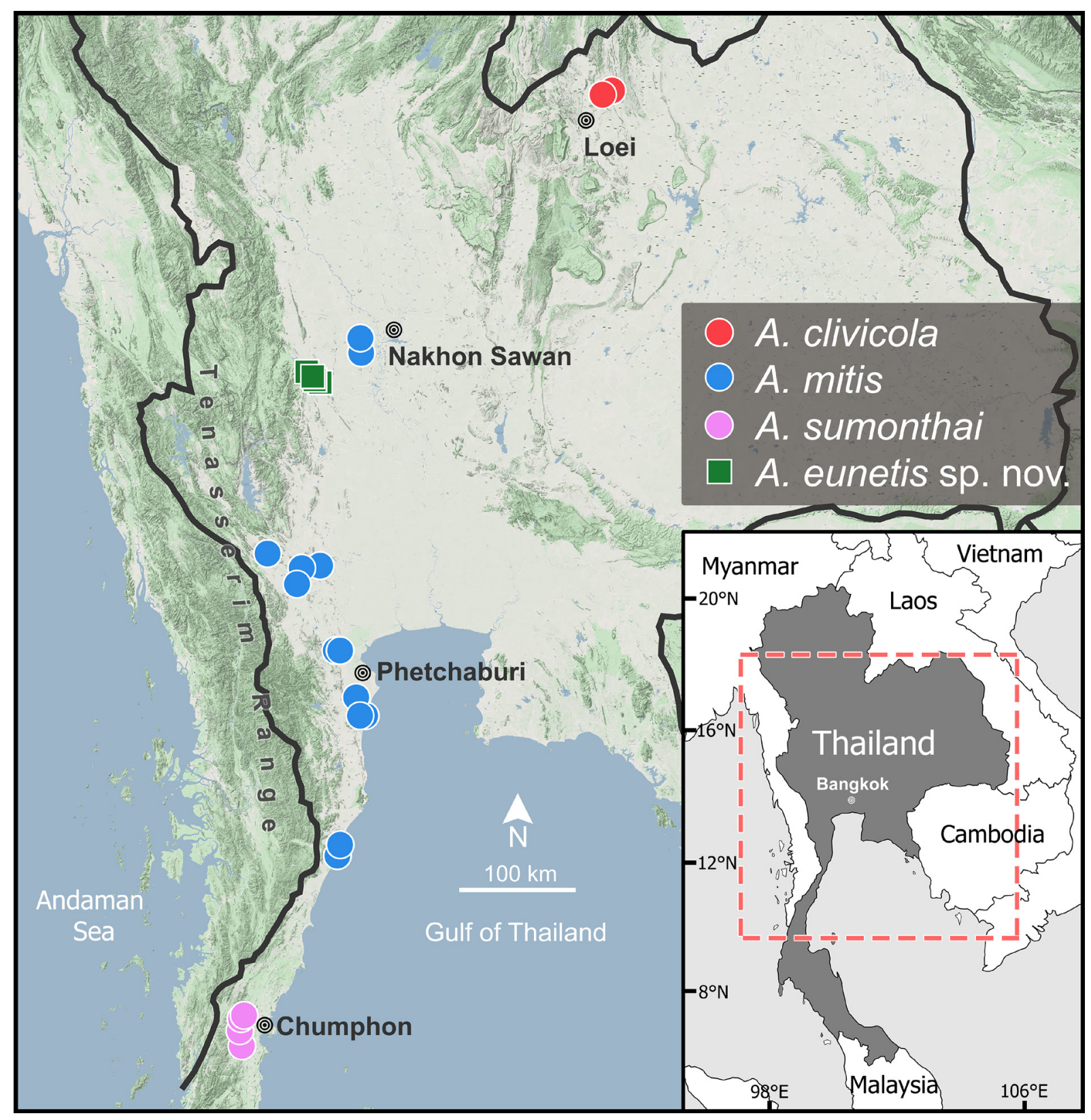

Fig. 1. Geographic distribution of four species of Aenigmatoconcha Tumpeesuwan \& Tumpeesuwan, 2017 based on specimens examined herein. 
Table 1. Information of all specimens used in the molecular phylogenetic study.

\begin{tabular}{|c|c|c|c|}
\hline $\begin{array}{l}\text { Species/ } \\
\text { specimen code }\end{array}$ & CUMZ code & Locality & $\begin{array}{r}\text { GenBank } \\
\text { Number }\end{array}$ \\
\hline \multicolumn{4}{|c|}{$\begin{array}{l}\text { Helicarionidae Bourguignat, } 1877 \\
\text { Aenigmatoconcha Tumpeesuwan \& Tumpeesuwan, } 2017\end{array}$} \\
\hline \multicolumn{4}{|c|}{ A. clivicola Tumpeesuwan \& Tumpeesuwan, 2017} \\
\hline NE12 & 7928 & Loei Province, Thailand & MN897082 \\
\hline NE68-1 & 7929.1 & Loei Province, Thailand & MW703614 \\
\hline NE68-2 & 7929.2 & Loei Province, Thailand & MW703615 \\
\hline NE68-3 & 7929.3 & Loei Province, Thailand & MW703616 \\
\hline \multicolumn{4}{|c|}{ A. mitis (Pfeiffer, 1863) } \\
\hline $\mathrm{C} 25$ & 7885 & Nakhon Sawan Province, Thailand & MW703617 \\
\hline $\mathrm{C} 26$ & 7849 & Nakhon Sawan Province, Thailand & MW703618 \\
\hline W6 & 7920 & Phetchaburi Province, Thailand & MW703619 \\
\hline W8 & 7914 & Kanchanaburi Province, Thailand & MW703620 \\
\hline W47 & 7921.1 & Phetchaburi Province, Thailand & MW703621 \\
\hline W50 & 7921.2 & Phetchaburi Province, Thailand & MW703622 \\
\hline W56 & 7916 & Prachuap Khiri Khan Province, Thailand & MW703623 \\
\hline W57 & 7915 & Prachuap Khiri Khan Province, Thailand & MW703624 \\
\hline W88 & 7917 & Phetchaburi Province, Thailand & MW703625 \\
\hline W89 & 7918 & Phetchaburi Province, Thailand & MW703626 \\
\hline \multicolumn{4}{|c|}{ A. sumonthai Tumpeesuwan \& Tumpeesuwan, 2018} \\
\hline S79 & 7926 & Chumphon Province, Thailand & MW703627 \\
\hline S80 & 7922 & Chumphon Province, Thailand & MN897083 \\
\hline S109 & 7925 & Chumphon Province, Thailand & MW703628 \\
\hline S162-2 & 7927.2 & Chumphon Province, Thailand & MW703629 \\
\hline \multicolumn{4}{|c|}{ A. eunetis Pholyotha \& Panha sp. nov. } \\
\hline $\mathrm{C} 8$ & 7935 & Uthai Thani Province, Thailand & MW703630 \\
\hline $\mathrm{C} 10-1$ & 7933.1 & Uthai Thani Province, Thailand & MW703631 \\
\hline $\mathrm{C} 10-3$ & 7933.3 & Uthai Thani Province, Thailand & MW703632 \\
\hline $\mathrm{C} 24$ & 7936 & Uthai Thani Province, Thailand & MW703633 \\
\hline \multicolumn{4}{|l|}{ Other genera } \\
\hline \multicolumn{4}{|c|}{ Helicarionidae Bourguignat, 1877} \\
\hline \multicolumn{3}{|c|}{ Sophina schistostelis schistostelis (Benson, 1859) } & MN897023 \\
\hline \multicolumn{3}{|c|}{ Sophina conjungens Stoliczka, 1871} & MN897033 \\
\hline \multicolumn{3}{|c|}{ Sophina bensoni Blanford \& Godwin-Austen, 1908} & MN897051 \\
\hline \multicolumn{3}{|c|}{ Sophina discoidalis Stoliczka, 1871} & MN897041 \\
\hline \multicolumn{3}{|c|}{ Chalepotaxis infantilis (Gredler, 1881) } & KX027275 \\
\hline \multicolumn{4}{|c|}{ Ariophantidae Godwin-Austen, 1883} \\
\hline \multirow{2}{*}{\multicolumn{3}{|c|}{$\begin{array}{l}\text { Sarika resplendens (Philippi, 1846) } \\
\text { Sarika resplendens (Philippi, 1846) }\end{array}$}} & MT364982 \\
\hline & & & MT364983 \\
\hline
\end{tabular}


Identification of species followed the original descriptions (Pfeiffer 1863; Tumpeesuwan \& Tumpeesuwan 2017, 2018) and were then compared to the relevant type specimens. For the descriptive work, living snails, shells, and whole genitalia were imaged using a Nikon camera (DSLR D850) with a Nikon 105 Macro lens (AF-S VR Micro-Nikkor 105mm f/2.8G IF-ED). The number of shell whorls was counted and shells were measured using a Vernier calliper. Three to 20 specimens of each species were examined under an Olympus SZX2-TR30 stereoscopic light microscope. The inner sculpture of genitalia was imaged by a stereo microscope with the Cell'D Imaging Software. Radulae were extracted, soaked in $10 \%(\mathrm{w} / \mathrm{v})$ sodium hydroxide, cleaned with distilled water, and imaged by scanning electron microscopy (SEM; JEOL, JSM-6610 LV).

\section{Molecular studies}

Genomic DNA extraction, amplification, and sequencing

Genomic DNA was extracted from the foot tissue using a NucleoSpin Tissue kit (Macherey-Nagel, Germany), according to the manufacturer's instructions. For sequencing the partial COI gene fragment, the universal primer pair LCO1491 (5'-GGTCAACAAATCATAAAGATATTGG-3') and HCO2198 (5'-TAAACTTCAGGGTGACCAAAAAATCA-3') (Folmer et al. 1994) were used for PCR amplification. PCR cycling was performed as $94^{\circ} \mathrm{C}$ for $1 \mathrm{~min}$, followed by 40 cycles of $98^{\circ} \mathrm{C}$ for $10 \mathrm{~s}$, $51^{\circ} \mathrm{C}$ for $30 \mathrm{~s}$, and $72^{\circ} \mathrm{C}$ for $90 \mathrm{~s}$, and then followed by a final $72^{\circ} \mathrm{C}$ for $5 \mathrm{~min}$. The PCR products were commercially sequenced by Bioneer Co., Korea. To achieve a single consensus sequence, individual forward and reverse sequence traces were aligned and edited using ClustalW, as implemented in the MEGA7 software (Kumar et al. 2016). A total of 20 new COI gene sequences were subsequently uploaded and stored in GenBank under accession numbers: MW703614-MW703633. Information of all samples included in this analysis is given in Table 1.

\section{COI analyses}

The 20 new COI gene sequences from this study and nine sequences from GenBank were aligned using ClustalW, as implemented in the MEGA7 software (Kumar et al. 2016). The partitioning and substitution model choice for the COI alignment were done in the program Kakusan4 (Tanabe 2011), using a heuristic search algorithm and under the Akaike Information Criterion (AIC). The Kakusan4 program suggested dividing the dataset into three partitions (the three codon positions of COI) and gave the best-fit models for each partition as the general time reversible model with gamma distribution for the first and the second COI codon positions, and the HKY model with gamma distribution for the third COI codon position.

Maximum likelihood (ML) and Bayesian inference(BI) were used to estimate the phylogenetic relationships and were performed online through the Cyber Infrastructure for Phylogenetic Research (CIPRES) Science Gateway (Miller et al. 2010). The RAxML-HPC2 program on XSEDE v. 8.2.12 software (Stamatakis 2014) was used to carry out the ML analysis, with 1000 bootstrap replicates, by applying the GTRCAT model. The BI analysis was performed in MrBayes on XSEDE v. 3.2.7a (Ronquist et al. 2012) with two independent Markov chain Monte Carlo (MCMC) simulations. The analysis ran the MCMC simulation for 10 million generations (default heating parameters) with sampling every 1000 generations. All parameters from both runs were checked for convergence and stationarity by visualizing the plot of generation vs the log-probability and checking the values of the estimated sample size (ESS) were more than 200 using Tracer v.1.6 (Rambaut et al. 2014). The BI trees generated during the first $25 \%$ of the generations were discarded as burn-in. Nodes having ML bootstrap support values (BS) of $\geq 70 \%$ and BI posterior probabilities (PP) of $\geq 0.95$ were considered to be significantly supported (Hillis \& Bull 1993; Felsenstein 2004; Huelsenbeck \& Rannala 2004; Mauro \& Agorreta 2010; Hirano et al. 2018). Genetic sequence divergences in the COI gene among and within the species of Aenigmatoconcha together with other helicarionoids were calculated using uncorrected $p$-distances as implemented in the MEGA7 software (Kumar et al. 2016). 


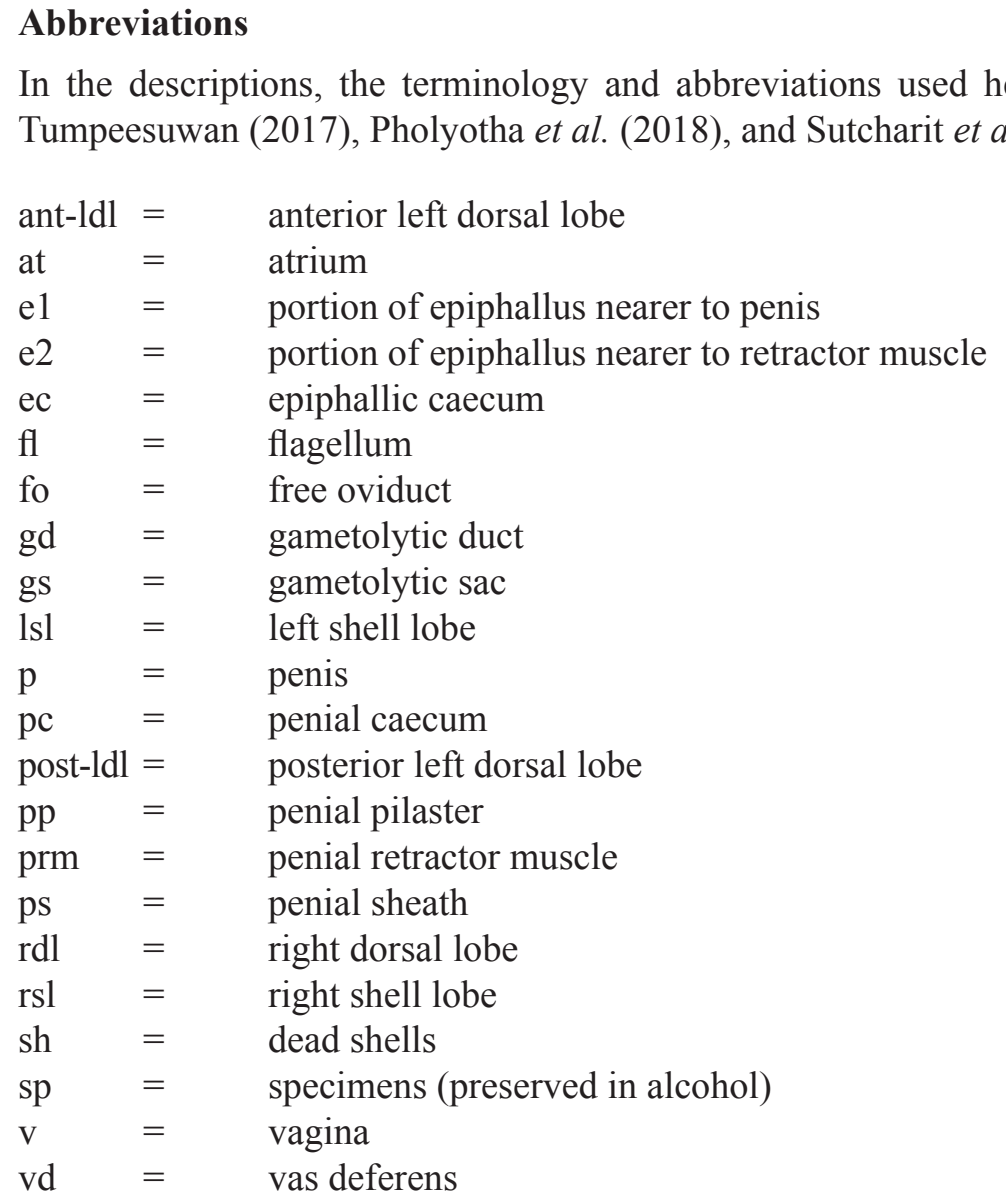

\section{Institutional abbreviations}

CUMZ $=\quad$ Chulalongkorn University, Museum of Zoology, Bangkok, Thailand

NHM $=$ The Natural History Museum, London, United Kingdom (NHMUK-when citing specimen lots deposited in the NHM)

\section{Results}

\section{COI phylogeny}

The final sequence dataset contained sequences of 22 Aenigmatoconcha specimens together with five helicarionid specimens (one sequence of Chalepotaxis Ancey, 1887 and four sequences of Sophina Benson, 1859) included as related taxa based on a molecular phylogeny of some Asian Helicarionidae (Sutcharit et al. 2020a). In addition, two specimens of Sarika Godwin-Austen, 1907 from the family Ariophantidae were used to root the trees. The final COI alignment had a total length of 655 aligned nucleotides, containing 209 variable sites and 177 parsimony informative sites. The COI dataset did not resolve the phylogenetic relationships among Aenigmatoconcha, Chalepotaxis, and Sophina (Fig. 2), yet it did retrieve each of the four Aenigmatoconcha species as well-supported clades (Fig. 2). The relationships between the four species, however, remain unclear.

The mean uncorrected p-distance of the COI gene among Aenigmatoconcha, Chalepotaxis, and Sophina ranged from $12.5 \%$ to $14.1 \%$ (Table 3). Among Aenigmatoconcha lineages, the average uncorrected p-distance of the COI gene ranged from $9.7 \%$ to $12.0 \%$ (Table 4). The intraspecific genetic distances within each lineage ranged from $0.2 \%$ to $4.2 \%$ (Table 4 ). 

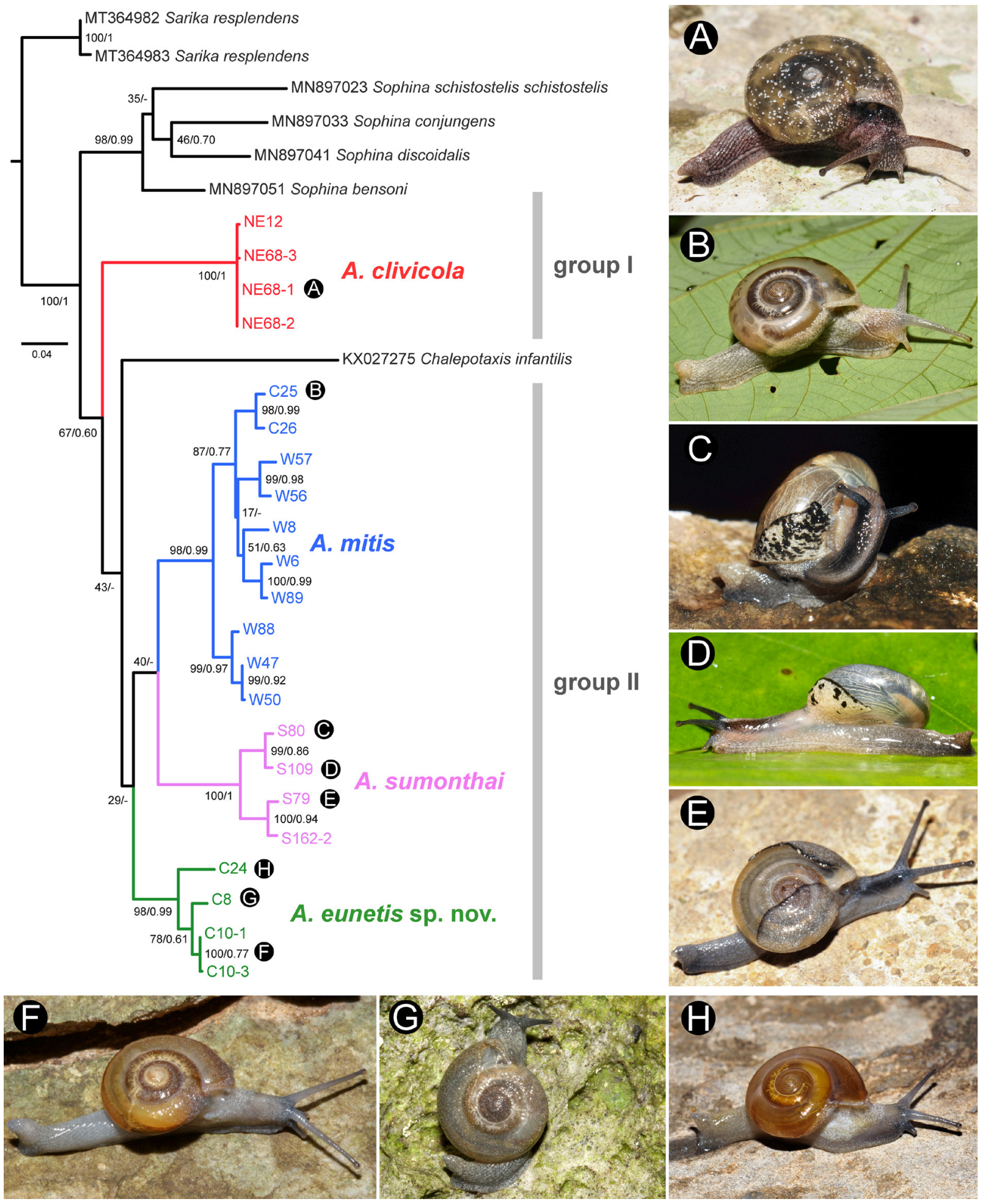

Fig. 2. Maximum likelihood tree of Aenigmatoconcha Tumpeesuwan \& Tumpeesuwan, 2017 based on the COI gene dataset. Numbers on nodes indicate the ML bootstrap values (left) and Bayesian posterior probabilities (right) values. Pictures of living snails are not to scale. 
Table 2. Comparison of the morpho-anatomical characteristics of Aenigmatoconcha Tumpeesuwan \& Tumpeesuwan, 2017: species, Chalepotaxis Ancey, 1887 and Sophina Benson, 1859. Superscript numbers indicate the source reference: ${ }^{1}$ this study, ${ }^{2}$ Páll-Gergely et al. (2016) and ${ }^{3}$ Sutcharit et al. (2020a).

\begin{tabular}{|c|c|c|c|c|c|c|c|}
\hline \multirow[b]{2}{*}{ Taxa } & \multirow{2}{*}{$\begin{array}{l}\text { No. } \\
\text { mantle } \\
\text { lobes }\end{array}$} & \multirow[b]{2}{*}{ Shell shape } & \multirow[b]{2}{*}{ Radular teeth } & \multicolumn{4}{|l|}{ Genitalia } \\
\hline & & & & $\begin{array}{l}\text { Dart } \\
\text { apparatus }\end{array}$ & $\begin{array}{l}\text { Epiphallic } \\
\text { caecum }\end{array}$ & Flagellum & $\begin{array}{l}\text { Inner penial } \\
\text { sculpture }\end{array}$ \\
\hline A. clivicola ${ }^{1}$ & 5 & $\begin{array}{l}\text { Strongly } \\
\text { depressed to } \\
\text { depressed }\end{array}$ & $\begin{array}{l}\text { V-shaped rows / } \\
\text { monocuspid with } \\
\text { spatulate shape }\end{array}$ & Absent & Long & Present & $\begin{array}{l}\text { Oblique } \\
\text { trapezoid }\end{array}$ \\
\hline A. mitis ${ }^{1}$ & 5 & $\begin{array}{l}\text { Depressed } \\
\text { to globosely } \\
\text { depressed }\end{array}$ & $\begin{array}{l}\text { V-shaped rows / } \\
\text { monocuspid with } \\
\text { spatulate shape }\end{array}$ & Absent & Short & Present & $\begin{array}{l}\text { Small oblique } \\
\text { wrinkled }\end{array}$ \\
\hline A. sumonthai ${ }^{1}$ & 5 & $\begin{array}{l}\text { Strongly } \\
\text { depressed to } \\
\text { depressed }\end{array}$ & $\begin{array}{l}\text { V-shaped rows / } \\
\text { monocuspid with } \\
\text { spatulate shape }\end{array}$ & Absent & Short & Present & Small conical \\
\hline $\begin{array}{l}\text { A. eunetis sp. } \\
\text { nov. }{ }^{1}\end{array}$ & 5 & $\begin{array}{l}\text { Depressed } \\
\text { to globosely } \\
\text { depressed }\end{array}$ & $\begin{array}{l}\text { Wide-angle U-shape } \\
\text { rows / } \\
\text { monocuspid with } \\
\text { oblong shape }\end{array}$ & Absent & Short & Present & Small conical \\
\hline Chalepotaxis $^{2}$ & - & $\begin{array}{l}\text { Depressed } \\
\text { conical }\end{array}$ & $\begin{array}{l}\text { V-shaped rows / } \\
\text { monocuspid with } \\
\text { spatulate shape }\end{array}$ & Absent & Short & Absent & - \\
\hline Sophina ${ }^{3}$ & 4 & $\begin{array}{l}\text { Depressed } \\
\text { to globosely } \\
\text { depressed }\end{array}$ & $\begin{array}{l}\text { V-shaped rows / } \\
\text { monocuspid with } \\
\text { spatulate shape }\end{array}$ & Present & Short & Absent & - \\
\hline
\end{tabular}

\section{Taxonomy}

Phylum Mollusca Linnaeus, 1758

Class Gastropoda Cuvier, 1795

Superfamily Helicarionoidea Bourguignat, 1877

Family Helicarionidae Bourguignat, 1877

Subfamily Durgellinae Godwin-Austen, 1888

Genus Aenigmatoconcha Tumpeesuwan \& Tumpeesuwan, 2017

Aenigmatoconcha Tumpeesuwan \& Tumpeesuwan, 2017: 182-184.

Aenigmatoconcha - Tumpeesuwan \& Tumpeesuwan 2018: 171.

\section{Type species}

Aenigmatoconcha clivicola Tumpeesuwan \& Tumpeesuwan, 2017, by original designation.

\section{Description}

Shell dextral with 5-51/2 convex whorls, strongly depressed to globosely depressed, medium-sized, thin to slightly solid, translucent, and pale milky to whitish-horny in colour. Shell surface smooth, glossy, and varix usually present. Body whorl well-rounded to slightly-shouldered. Suture shallow. Aperture slightly to very crescentic in shape with simple lip. Umbilicus open and deep. 
Table 3. Average genetic divergences among Aenigmatoconcha Tumpeesuwan \& Tumpeesuwan, 2017, Sophina Benson, 1859, Chalepotaxis Ancey, 1887, and Sarika Godwin-Austen, 1907 (Ariophantidae Godwin-Austen, 1883) and among species within each of these genera from the mitochondrial COI gene fragment sequences estimated by uncorrected $p$-distances.

\begin{tabular}{lcccc}
\hline Genera & Aenigmatoconcha & Chalepotaxis & Sophina & Sarika \\
\hline Aenigmatoconcha & 0.087 & - & - & - \\
Chalepotaxis & 0.130 & - & - & - \\
Sophina & 0.125 & 0.141 & 0.095 & - \\
Sarika & 0.119 & 0.140 & 0.123 & 0.008 \\
\hline
\end{tabular}

Animal with reticulated skinand whitish, yellowish, pale fleshy grey to dark brown body with tiny whitish dots irregularly scattered over entire body. Mantle lobes well-developed (two shell lobes and three dorsal lobes; see Figs 3, 5A). Shell lobes can cover most, if not all of the shell and are retracted when disturbed. Left and right shell lobes very thin, translucent, ovate to triangular in shape; right shell lobe (rsl) smaller than left shell lobe (lsl). Dorsal lobes enlarged, crescent-shaped, covering body, and smaller than shell lobes. Anterior left dorsal lobe (ant-ldl) and posterior left dorsal lobe (post-ldl) smaller than right dorsal lobe ( $\mathrm{rdl}$ ). Sole tripartite, lateral foot margin, caudal fossa, and caudal horn present.

Genitalia with moderately long to very long penis, thick penial sheath, short to long epiphallus, small flagellum, and short vagina. Gametolytic organ with short gametolytic duct and bulbous gametolytic sac. Oviduct with large lobules; prostate gland running alongside oviduct.

Radular teeth arranged in anteriorly V-shaped or wide-angle U-shaped rows; central tooth symmetrical monocuspid and spatulate or oblong in shape; lateral and marginal teeth undifferentiated, asymmetrical monocuspid and spatulate or oblong in shape, and outermost teeth gradually reduced in size.

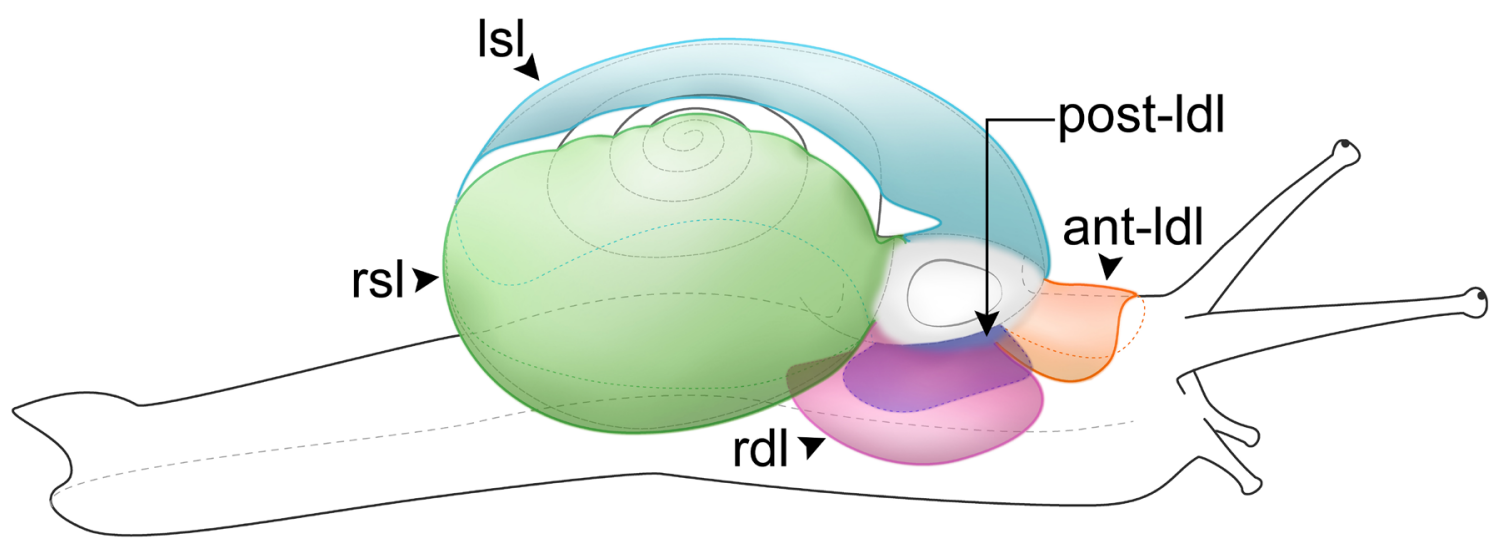

Fig. 3. Schematic drawing of living species of Aenigmatoconcha Tumpeesuwan \& Tumpeesuwan, 2017, emphasizing the relative size, position and arrangement of mantle lobes (two shell lobes and three dorsal lobes). 
Table 4. Average inter- and intra-specific $p$-distances of the mitochondrial COI gene fragment sequences on species of Aenigmatoconcha Tumpeesuwan \& Tumpeesuwan, 2017.

\begin{tabular}{lcccc}
\hline Aenigmatoconcha spp. & A. clivicola & A. mitis & A. sumonthai & $\begin{array}{c}\text { A. } \text { eunetis } \\
\text { sp. nov. }\end{array}$ \\
\hline A. clivicola & 0.002 & - & - & - \\
A. mitis & 0.112 & 0.042 & - & - \\
A. sumonthai & 0.120 & 0.102 & 0.034 & - \\
A. eunetis sp. nov. & 0.106 & 0.099 & 0.097 & 0.027 \\
\hline
\end{tabular}

\section{Distribution}

Species of Aenigmatoconcha exhibit allopatric distributions and are restricted to limestone karsts in Thailand (Fig. 1).

Aenigmatoconcha clivicola Tumpeesuwan \& Tumpeesuwan, 2017

Figs 1, 2A, 4A-B, 5, 10A

Aenigmatoconcha clivicola Tumpeesuwan \& Tumpeesuwan, 2017: 184-187, figs 2-5. Type locality: Phu Pha Lom Limestone Hill in Mueang District, Loei Province, northeastern Thailand.

Aenigmatoconcha clivicola - Tumpeesuwan \& Tumpeesuwan 2018: 171.

\section{Material examined}

THAILAND • 39 sh, 22 sp; Loei Province, Mueang District, Phu Pha Lom Limestone Hill; 17³3'16.6" N, $101^{\circ} 52^{\prime} 05.4^{\prime \prime}$ E; CUMZ 7928 • 6 sh, 12 sp; same collection data as for preceding; CUMZ 7929 - 48 sh; Loei Province, Na Duang District, Limestone outcrops at Wat Tham Pha Ya; $17^{\circ} 34^{\prime} 40.1^{\prime \prime} \mathrm{N}$, 10153'35.1" E; CUMZ 7930.

\section{Description}

SHELl (Fig. 4A-B). Shell strongly depressed to depressed, medium-sized (shell width 17.2-20.1 mm, shell height $8.6-10.0 \mathrm{~mm}$ ), rather thin to slightly solid and translucent, milky to pale whitish-horny colour, well-rounded body whorl, little elevated spire, impressed suture, obvious varix, and open umbilicus.

External FEATURes (Figs 2A, 5A). Animal with five well-developed mantle lobes. Left and right shell lobes thin, pale yellowish to fleshy-grey colour and spread with small whitish dots. Three dorsal lobes crescent-shaped and smaller than shell lobes.

Genitalia (Fig. 5B-D). Atrium (at) enlarged and very short. Penis (p) rather long cylindrical, penial sheath (ps) very thick and covering entire penis, and penial caecum (pc) rather small protruding. Inner wall of penis covered with trapezoid-shaped penial pilasters (pp) arranged in oblique rows. Epiphallus $(\mathrm{e} 1+\mathrm{e} 2)$ as long as penis: e1 long and slender, and e 2 bulbous and about half e1 length. Inner sculpture of e1 with very small and thin longitudinal folds to nearly smooth surface. Inner sculpture of e2 trapezoid to conical pilasters. Epiphallic caecum (ec) long with thick penial retractor muscle (prm) attached at tip. Flagellum (fl) small and short.

RADULA (Fig. 10A). Teeth arranged in anteriorly V-shaped rows with half row consisting of about 70 76 teeth at middle plate. Central, lateral, and marginal teeth monocuspid and spatulate-shaped with curved cusp. 


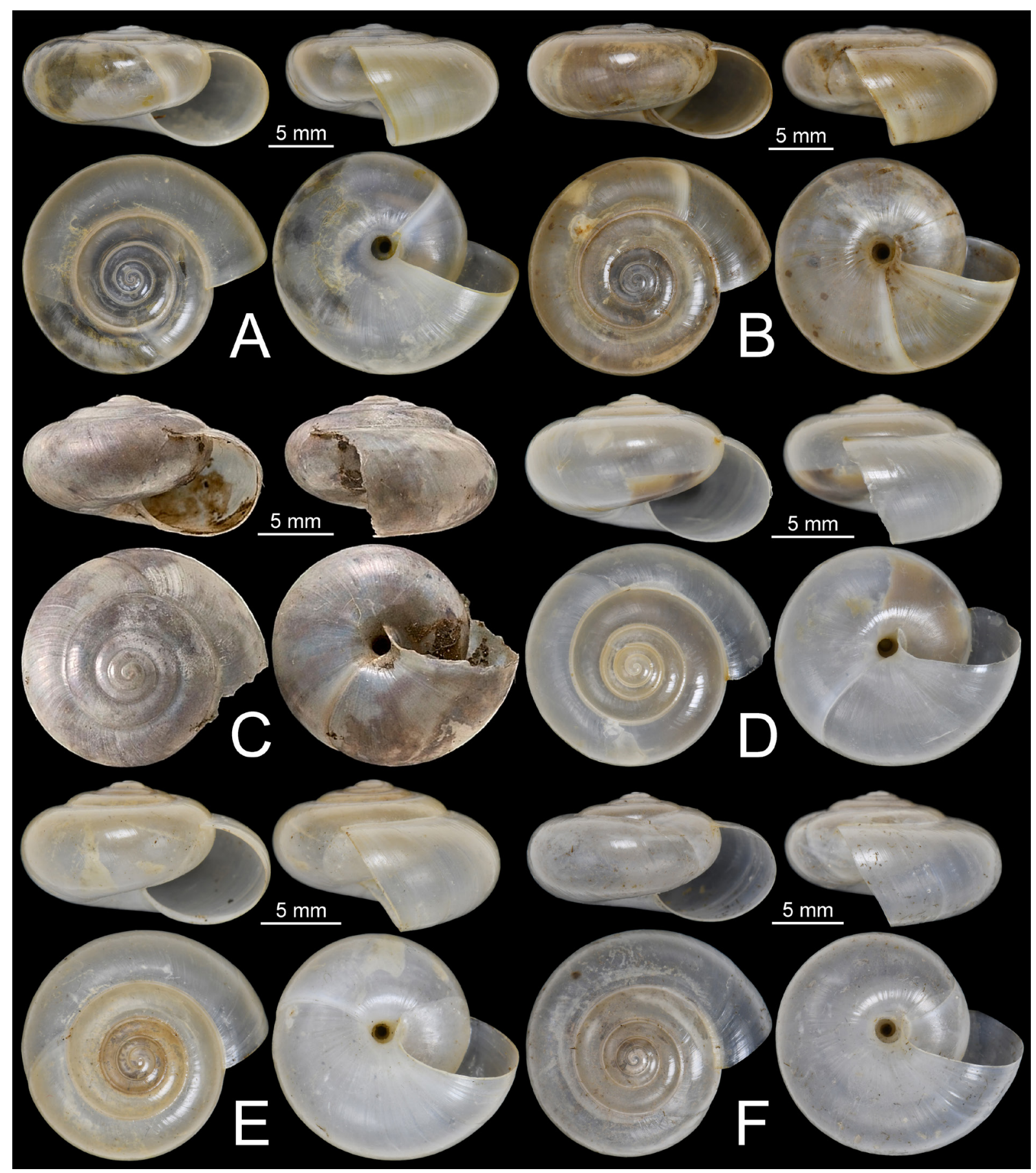

Fig. 4. Shells of Aenigmatoconcha spp. A-B. A. clivicola Tumpeesuwan \& Tumpeesuwan, 2017, specimen CUMZ 7928 from the type locality (A) and specimen CUMZ 7930 from Loei Province (B). C-F. A. mitis (Pfeiffer, 1863) comb. nov., syntypes NHMUK ex. Cuming collection (C), specimen CUMZ 7921 from Phetchaburi Province (D), specimen CUMZ 7687 from Kanchanaburi Province (E), and specimen CUMZ 7885 from Nakhon Sawan Province (F). 


\section{Distribution}

This species is currently known only from 2 localities: the type locality (Phu Pha Lom) and limestone hills in Loei Province (Fig. 1).

\section{Remarks}

The genitalia were originally described but without examination of the internal sculpture of penis. In this study, we examined 20 adult topotypic specimens to provide descriptions of the penial sheath, penial caecum, and flagellum that were not included in the original description. The penial sheath is very large and covers the entire penis (Fig. 5B). The short penial caecum, an extension of the penis, is located near the penis and epiphallus junction (Fig. 5B). This character is visible when penial sheath is removed. Its internal sculpture is rather smooth, unlike the penial sculpture, with its trapezoid-shaped pilasters (Fig. 5C). The Australian helicarionids, Nitor whitneyae Stanisic, 2010 has a penial caecum while other Nitor taxa do not have a penial caecum (Hyman \& Köhler 2018). In Southeast Asian ariophantids, the presence or absence of a penial caecum is a discriminating character among species in genera such as Macrochlamys Gray, 1847 and Taphrenalla Pholyotha \& Panha, 2020, and is supported by molecular studies (Pholyotha et al. 2018, 2021). The flagellum of A. clivicola is an extension of the epiphallus and is located near the insertion point of the vas deferens. It is somewhat small and short, and bound to the vas deferens by thin connective tissue. This feature is important for spermatophore formation before copulation (Tompa 1984; Baur 2010). However, during this study no spermatophores were observed in A. clivicola.

Aenigmatoconcha mitis (Pfeiffer, 1863) comb. nov.

Figs 1, 2B, 4C-F, 6, 10B

Helix mitis Pfeiffer, 1863[1862]: 268. Type locality: Lao Mountains, Camboja [Lao Mountains, Cambodia].

Helix mitis - Pfeiffer 1868: 141. — Tryon 1886: 171.

Ariophanta (Kaliella) mitis - Fischer 1891: 21.

Hyalinia mitis - Fischer \& Dautzenberg 1904: 396.

Macrochlamys (?) mitis - Inkhavilay et al. 2019: 78, 79, fig. 37b.

\section{Material examined}

\section{Syntypes}

CAMBODIA • 2 sh; "Lao Mountains, Camboja" [Lao Mountains, Cambodia]; NHMUK ex. Cuming collection.

\section{Other material}

THAILAND • 37 sh, 16 sp; Nakhon Sawan Province, Mueang District, Limestone outcrops at Wat Tham Bo Ya; $15^{\circ} 43^{\prime} 47.3^{\prime \prime}$ N, 9956'44.7" E; CUMZ 7708 • 30 sh, 15 sp; same collection data as for preceding; CUMZ 7885 8 sh, 21 sp; Nakhon Sawan Province, Krok Phra District, Limestone outcrops at Wat Khao Tham Phra; 15³3'30.2" N, 9957'28.1" E; CUMZ 7849 • 3 sp; Kanchanaburi Province, Sai Yok District, Limestone outcrops at Wat Thep Thepa Satthatham; $14^{\circ} 03^{\prime} 56.6^{\prime \prime}$ N, 99 $11^{\circ} 45.7^{\prime \prime}$ E; CUMZ 7913 • 21 sh, 24 sp; Kanchanaburi Province, Mueang District, Limestone outcrops at Wat Tham Charoentham; $13^{\circ} 55^{\prime} 59.1^{\prime \prime}$ N, 99²7'59.9" E; CUMZ 7687 • 3 sp; Kanchanaburi Province, Tha Muang District, Limestone outcrops at Wat Tham Faet; 1357'52.5" N, 99³4'56.1" E; CUMZ 7914 • 30 sh, $1 \mathrm{sp}$; Kanchanaburi Province, Dan Makham Tia District, Limestone outcrops at Wat Tham Khao Cha Ang; 134' $08.4^{\prime \prime}$ N, 99²6'33.2" E; CUMZ 7247 • 4 sh, 3 sp; Phetchaburi Province, Khao Yoi District,

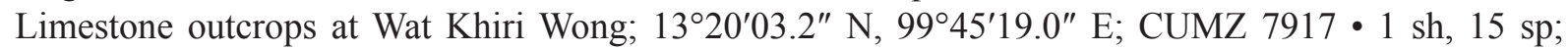
Phetchaburi Province, Khao Yoi District, Limestone outcrops at Wat Puang Malai; $13^{\circ} 18^{\prime} 46.0^{\prime \prime} \mathrm{N}$, 


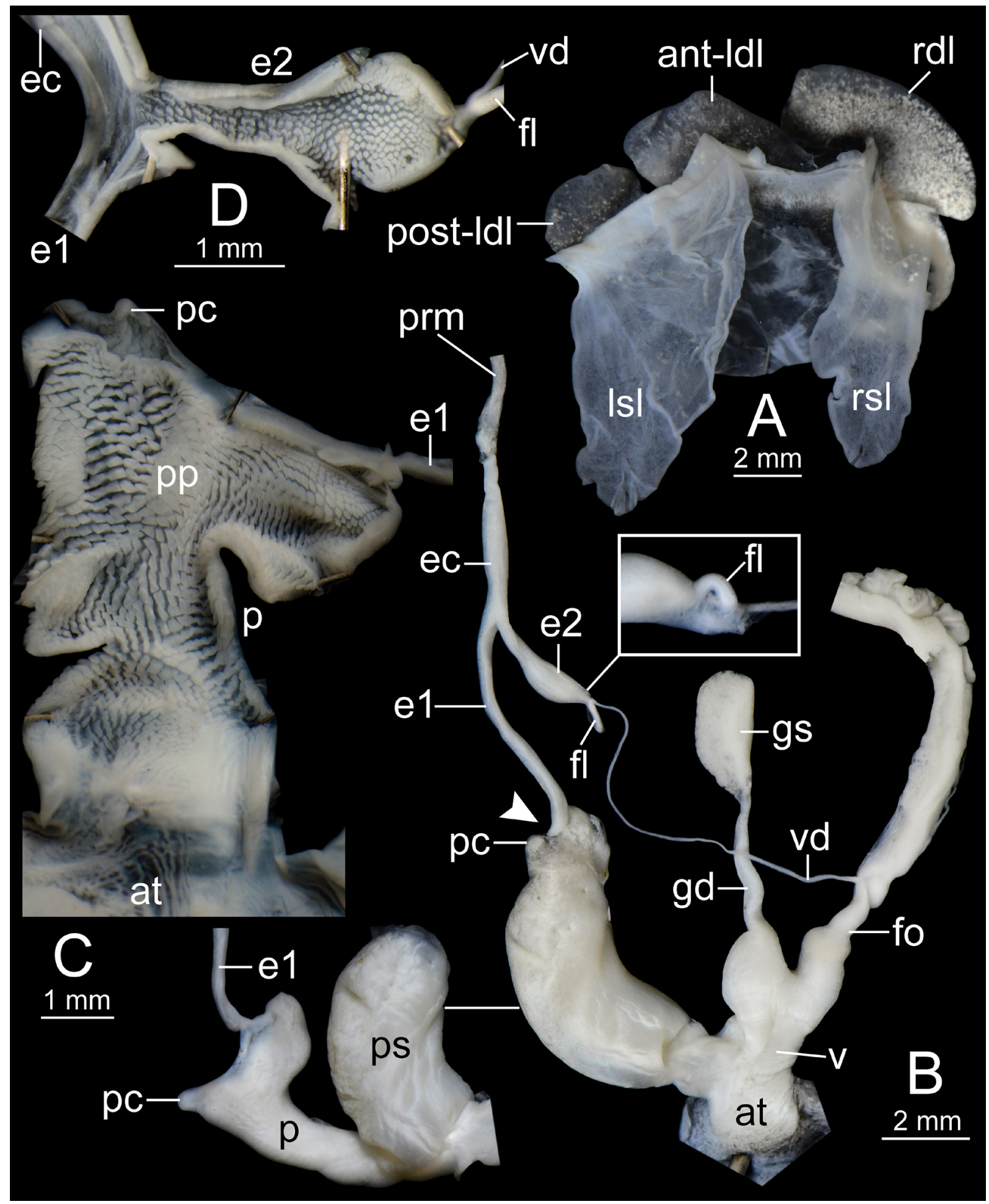

Fig. 5. Genital system and mantle lobes of Aenigmatoconcha clivicola Tumpeesuwan \& Tumpeesuwan, 2017, specimen CUMZ 7929 from the type locality. A. Mantle lobes. B. General view of genitalia; inset showing flagellum encircled with a loose tissue before clearing it out. C. Internal structure of penis. D. Internal structure of epiphallus and epiphallic caecum. White arrow indicates the junction between penis and epiphallus. 
9947'02.2" E; CUMZ 7921 • 9 sh; same collection data as for preceding; CUMZ 7938 • 5 sh, $14 \mathrm{sp}$; Phetchaburi Province, Tha Yang District, Limestone outcrops at Wat Khao Krachiu; 12 ${ }^{\circ} 7^{\prime} 41.3^{\prime \prime}$ N, 99 54'49.3" E; CUMZ 7918 • 3 sh, 16 sp; Phetchaburi Province, Cha-am District, Limestone outcrops at Khao Nang Panthurat; 12 50'20.5" N, 99 57'11.6" E; CUMZ 7920 • 2 sh, 2 sp; Phetchaburi Province, Cha-am District, Limestone outcrops at Tham Chaeng Bureau of Monks; 12 49'44.3" N, 99 56'27.1' E; CUMZ $7919 \bullet 4$ sh, 7 sp; Prachuap Khiri Khan Province, Mueang District, Limestone outcrops at Khao

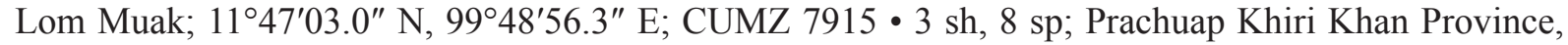
Mueang District, Limestone outcrops at Khao Ta Mong Lai; 1150'07.3" N, 9949'50.1" E; CUMZ 7916.

\section{Description}

SHELL (Fig. 4C-F). Shell depressed to globosely depressed, medium-sized (width 12.3-18.1 mm, height 6.9-9.9 mm), rather thin, and translucent. Shell surface smooth and glossy. Shell colour whitish to very pale horny-white. Whorls: $5-5 \frac{1}{2}$, regularly increasing in size; varix present; suture rather wide and shallow. Spire rather elevated. Last whorl broad and well-rounded. Aperture obliquely oval-lunate in shape; peristome simple. Columellar margin simple, slightly expanded near umbilicus. Umbilicus open and deep.

External Features (Fig. 2B). Living snails with reticulated skin and pale yellowish to dark grey body. Five well-developed mantle lobes; left and right shell lobes thin, pale yellowish, spread with small whitish dots, and left shell lobe larger than right shell lobe. Three dorsal lobes broad and crescentshaped; right dorsal lobe larger than anterior and posterior left dorsal lobes. Caudal fossa present; caudal horn raised, rather large, and whitish to pale fleshy-grey in colour.

Genitalia (Fig. 6). Atrium (at) enlarged and very short. Penis (p) long, cylindrical, and with slightly thick penial sheath (ps) encircling about half of penis length. Inner sculpture of penis with very small and oblique wrinkled penial pilasters ( $\mathrm{pp}$ ), and one large longitudinal fold running the length of the entire penis chamber. Epiphallus (e1 $+\mathrm{e} 2)$ approximately as long as penis: e1 slender and narrower than penis, and e 2 shorter and bulbous shape. Inner sculpture of e 1 with very small thin longitudinal folds to nearly smooth surface with one thickened longitudinal fold, and inner sculpture of e 2 with large papillae arranged in oblique rows. Epiphallic caecum (ec) very short; penial retractor muscle (prm) thin and attached at tip. Flagellum (fl) small and rather short. Vas deferens (vd) very long and thin. Vagina (v) very short and enlarged. Gametolytic duct (gd) long, slender, and enlarged near vagina; gametolytic sac (gs) very large and oblong shape. Free oviduct (fo) cylindrical, long, and encircled with thick tissue near vagina.

RADULA (Fig. 10B). Teeth arranged in anteriorly V-shaped rows with half row consisting of about 7679 teeth at middle plate. Central teeth symmetrical monocuspid, and spatulate-shaped with curved cusp. Lateral and marginal teeth undifferentiated, asymmetrical monocuspid, spatulate-shaped with curved cusp, and outermost teeth gradually reduced in size.

\section{Distribution}

The distribution of Aenigmatoconcha mitis is wider than all other recognised species. This species can be found in limestone areas ranging from central (Nakhon Sawan Province) to southern (Prachuap Khiri Khan Province) Thailand (Fig. 1).

\section{Remarks}

This species was originally described by L. Pfeiffer (1863) based on specimens in the collection of H. Cuming obtained from Henry Mouhot. The collection locality was brief: "Lao Mountains, Camboja". However, Mouhot's recorded localities were generally imprecise and referred to a wide geographical area, for example "Siam", "Lao Mountains, Camboja" and "Camboja". This has made it difficult to 


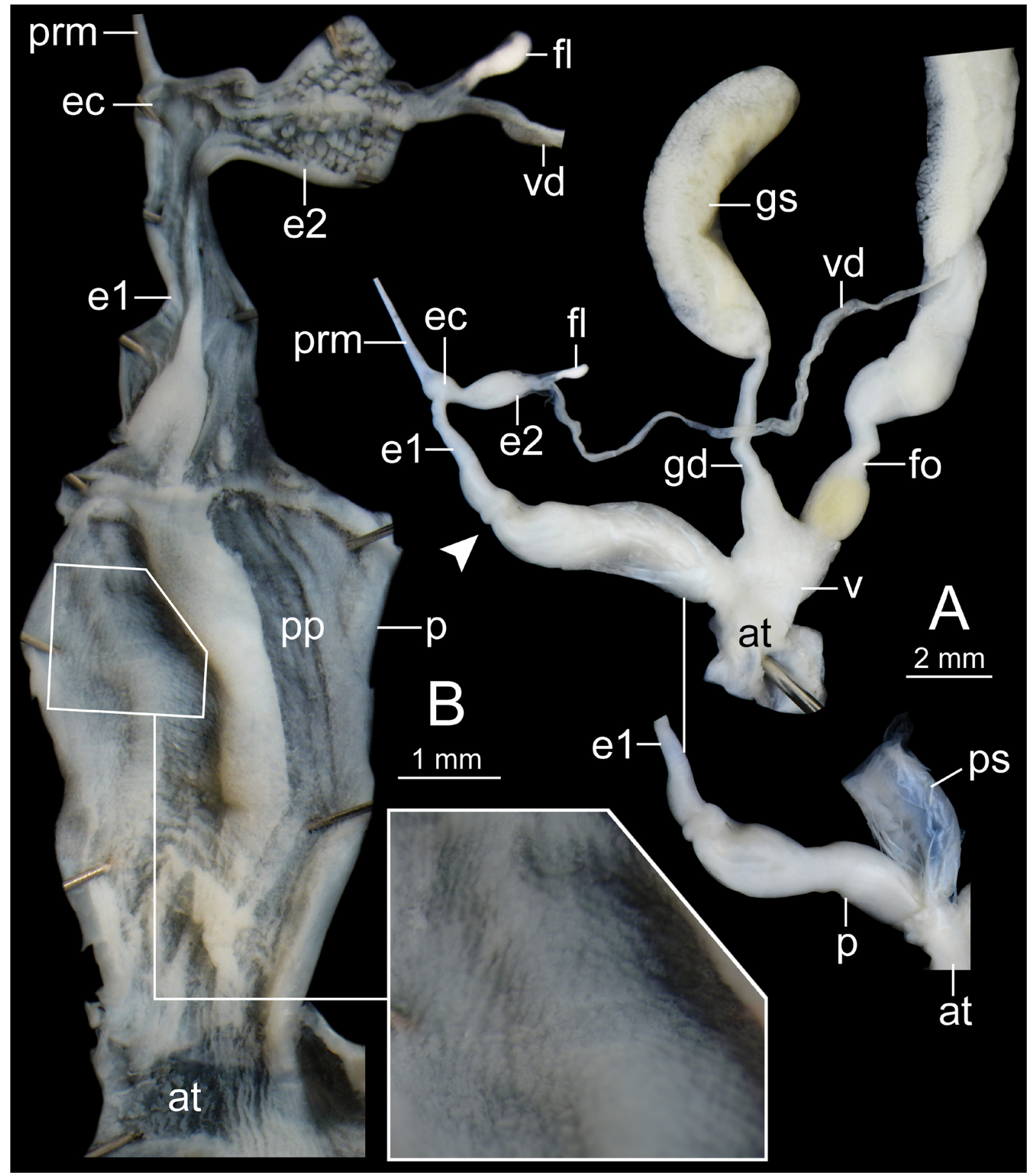

Fig. 6. Genital system of Aenigmatoconcha mitis (Pfeiffer, 1863) comb. nov., specimen CUMZ 7687 from Kanchanaburi Province. A. General view of genitalia. B. Internal structure of penis, epiphallus, and epiphallic caecum; inset showing penial sculpture. White arrow indicates the junction between the penis and epiphallus. 
infer more precise type localities of several land snail species described from Mouhot's specimens. No additional specimen records or literature references are available for this species until now. The most recent works on land snails from Laos and southern Cambodia confirmed the existence of $A$. mitis (Inkhavilay et al. 2019; Sutcharit et al. 2020c). Based on the recorded itinerary, H. Mouhot had travelled to "Pechaburi" [Petchaburi Province] in 1861, and clearly stated that he had visited caves and several hills during his four-month stay (Mouhot 1864: 57; Ashburton 1864: map). We have surveyed several limestone hills in western and peninsular Thailand and encountered numbers of empty shells and living specimens that well-matched with the type specimens of "Helix mitis Pfeiffer, 1863" (Fig. 4C). Therefore, peninsular Thailand (Petchaburi Province; Fig. 1) might be the area where H. Mouhot collected this species.

Aenigmatoconcha mitis exhibits a rather wide range of shell shape variation from depressed (Fig. 4F) to somewhat globose (Fig. 4C, D). However, the genitalia of these shell morphs are identical and the COI phylogeny also supports that all shell morphs are grouped together within the A. mitis clade (Fig. 2).

Aenigmatoconcha sumonthai Tumpeesuwan \& Tumpeesuwan, 2018

Figs 1, 2C-E, 7A-D, 8, 10C

Aenigmatoconcha sumonthai Tumpeesuwan \& Tumpeesuwan, 2018: 171-173, figs 2-6. Type locality: Tham Chang Phueak limestone range, Mueang District, Chumphon Province, southern Thailand.

\section{Material examined}

THAILAND • 45 sh, 20 sp; Chumphon Province, Mueang District, Limestone outcrops at Tham Chang Phuek Bureau of Monks; $10^{\circ} 26^{\prime} 50.0^{\prime \prime}$ N, 99 02'07.1" E; CUMZ 7922 • 40 sh; same collection data as for preceding; CUMZ 7923 • 18 sh, 10 sp; same collection data as for preceding; CUMZ $7937 \bullet 45 \mathrm{sh}$, 6 sp; Chumphon Province, Mueang District, Limestone outcrops at Wat Tham Sanook; 10²8'51.3" N, 9904'28.3" E; CUMZ 7924 • 10 sh, 7 sp; same collection data as for preceding; CUMZ 7925 • 22 sh, 11 sp; Chumphon Province, Sawi District, Limestone outcrops at Tham Nam Lod Thepnimit Bureau of Monks; 10²2'39.5" N, 9900'39.5" E; CUMZ 7927 • 4 sh, 8 sp; Chumphon Province, Sawi District, Limestone outcrops at Wat Nam Cha; 10¹7'57.0" N, 9901'58.5" E; CUMZ 7926.

\section{Description}

SHell (Fig. 7A-B). Shell strongly depressed to depressed, medium-sized (width 14.4-16.6 mm, height 7.0-8.2 mm), thin, translucent, whitish colour, well-rounded to slightly shouldered body whorl, elevated spire, impressed suture, obvious varix, and open umbilicus.

External Features (Fig. 2C-E). Animal with five well-developed mantle lobes. Left and right shell lobes pale yellowish to fleshy-grey colour, usually with black margin, and with or without small to large black spots or blotches. Three dorsal lobes crescent-shaped and smaller than the other two shell lobes. Black stripes behind long tentacles.

Genitalia (Fig. 8). Atrium (at) enlarged and very short. Penis (p) long, cylindrical with thick penial sheath (ps) extending to half of penis length. Inner sculpture of penis with small conical penial pilasters (pp). Epiphallus (e1 + e2) as long as penis: e1 slender, and e2 bulbous. Inner sculpture of e1 with small thin longitudinal folds, while e2 with small papillae arranged in oblique rows. Epiphallic caecum (ec) short with thin penial retractor muscle (prm) attached at tip. Flagellum (fl) small and short.

RADULA (Fig. 10C). Teeth arranged in anteriorly V-shaped rows with half row consisting of about 6365 teeth at the middle plate. All teeth monocuspid and spatulate-shaped with curved cusp. 


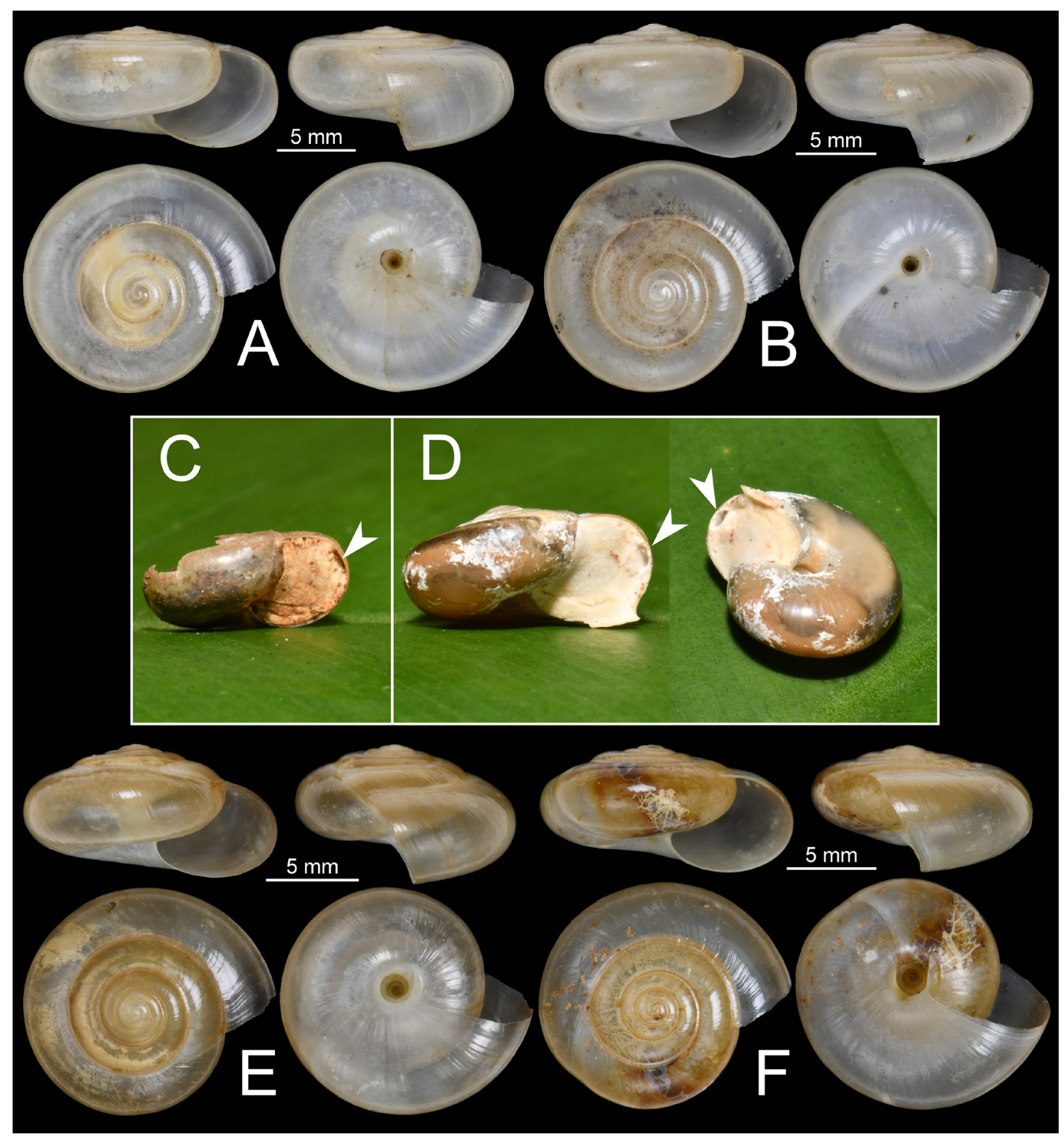

Fig. 7. Shells of Aenigmatoconcha spp. A-D. A. sumonthai Tumpeesuwan \& Tumpeesuwan, 2018. A-B. Specimen CUMZ 7922 from the type locality. C-D. Specimen CUMZ 7937 from the type locality showing the calcareous epiphragm with a small perforation (white arrows). Only shell (C) and living (D) specimens in both lateral and ventral views. E-F. A. eunetis Pholyotha \& Panha sp. nov. E. Holotype CUMZ 7931. F. Paratype CUMZ 7933 from Uthai Thani Province. 


\section{Distribution}

Aenigmatoconcha sumonthai has a narrow distribution, with populations living on a few limestone hills in Chumphon Province (Fig. 1). We extended our survey, especially among limestone sites about $200 \mathrm{~km}$ southwards down to southern peninsular Thailand, but we could not find this species elsewhere.

\section{Remarks}

The lack of a penial sheath and flagellum in the male reproductive organs of $A$. sumonthai was originally reported to be similar to A. clivicola (Tumpeesuwan \& Tumpeesuwan, 2018: 174, fig. 6). In this study, based on topotypic specimens, however, $A$. sumonthai was found to have a large and thickened penial sheath and small flagellum encircled with loose tissue (Fig. 8).

Aenigmatoconcha sumonthai shows variation in the black blotches on both shell lobes ranging from absent (Fig. 2E) to the lobes almost entirely covered (Fig. 2C). The DNA sequence analysis suggested that these variations formed a clade of $A$. sumonthai (Fig. 2). In addition, this species develops a calcareous epiphragm with a small perforation to limit body-water evaporation but allowing respiratory gas exchange during dormancy (Fig. 7C, D).

Aenigmatoconcha eunetis Pholyotha \& Panha sp. nov. urn:lsid:zoobank.org:act:98AD360F-93A3-4A8E-BE1A-5C991DBC358F

Figs 1, 2F-H, 7E-F, 9, 10D

\section{Diagnosis}

Shell medium-sized and pale yellowish white. Aperture ovate-lunate in shape and vertically open. Genitalia with very long and slender penis with many tiny conical penial pilasters inside. Radular teeth arranged in wide-angle U-shaped row, teeth with oblong shape, monocuspid.

\section{Etymology}

The specific name 'eunetis' is from the Greek word meaning 'spouses', honouring the authors of genus Aenigmatoconcha, who are married.

\section{Material examined}

\section{Holotype}

THAILAND • $1 \mathrm{sh}$ (width $13.9 \mathrm{~mm}$, height $7.4 \mathrm{~mm}$ ); Uthai Thani Province, Lan Sak District, Limestone outcrops at Tham Namthip Bureau of Monks; 15²6'00.3" N, 99³5'18.7" E; CUMZ 7931.

\section{Paratypes}

THAILAND • $1 \mathrm{sh}, 7 \mathrm{sp}$; same collection data as for holotype; CUMZ 7933 • $12 \mathrm{sp}$; same collection data as for holotype; CUMZ $7932 \cdot 2 \mathrm{sh}$; same collection data as for holotype; NHMUK.

\section{Other material}

THAILAND - $1 \mathrm{sp}$; Uthai Thani Province, Lan Sak District, Limestone outcrops at Hup Pa Tat; $15^{\circ} 22^{\prime} 36.5^{\prime \prime} \mathrm{N}, 99^{\circ} 37^{\prime} 49.5^{\prime \prime} \mathrm{E}$; CUMZ 7934 • 6 sp; same collection data as for preceding; CUMZ 7935 - 3 sh, 27 sp; Uthai Thani Province, Nong Chang District, Limestone outcrops at Wat Khao Bang Kraek; $15^{\circ} 18^{\prime} 07.9^{\prime \prime} \mathrm{N}, 99^{\circ} 41^{\prime} 04.5^{\prime \prime} \mathrm{E}$; CUMZ 7936.

\section{Description}

SHeLl (Fig. 7E-F). Depressed to globosely depressed, medium-sized (width 12.6-14.2 mm, height 6.1$7.1 \mathrm{~mm}$ ), thin and translucent. Shell surface smooth, and polished, and pale yellowish white. Whorls: $5-5 \frac{1}{2}$, regularly increasing in size, separated by shallow suture. Spire rather elevated; varix usually 


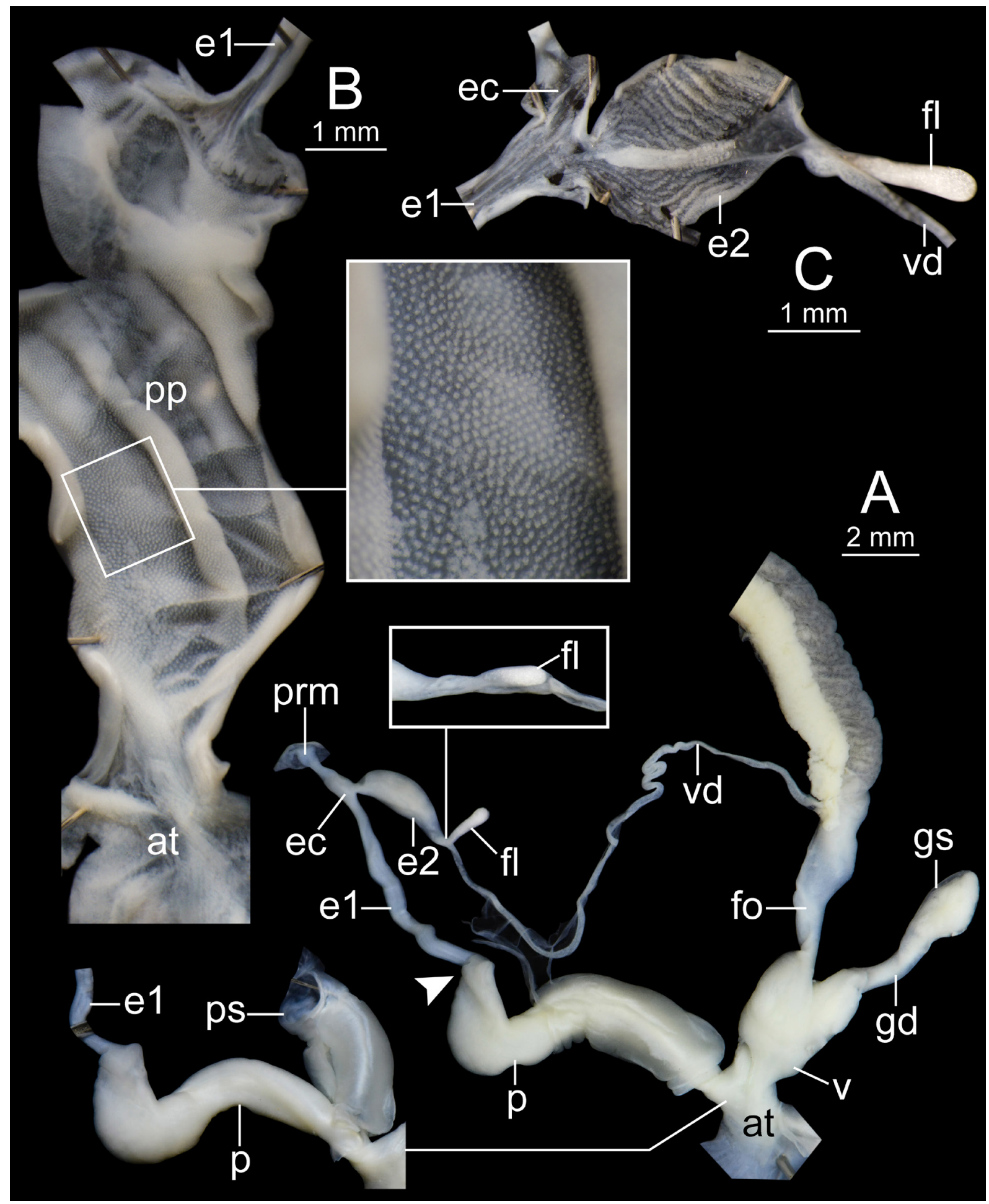

Fig. 8. Genital system of Aenigmatoconcha sumonthai Tumpeesuwan \& Tumpeesuwan, 2018, specimen CUMZ 7922 from the type locality. A. General view of genitalia; inset showing flagellum encircled with a loose tissue before clearing it out. B. Internal structure of penis; inset showing penial sculpture. C. Internal structure of epiphallus and epiphallic caecum. White arrow indicates the junction between the penis and epiphallus. 
present; last whorl well-rounded. Aperture very obliquely oval-lunate in shape; peristome simple. Columellar margin simple and slightly expanded near umbilicus. Umbilicus open and deep.

External FeAturEs (Fig. 2F-H). Living snails with reticulated skin and pale yellowish to slightly dark grey body. Five well-developed mantle lobes: left and right shell lobes translucent, same colour as body, covered by tiny whitish dots, right shell lobe smaller than left shell lobe. Dorsal lobes broad and crescent-shaped: right dorsal lobe larger than both anterior and posterior left dorsal lobes. Caudal fossa present; caudal horn raised and rather large, and same colour as body.

Genitalia (Fig. 9). Atrium (at) enlarged and very short. Penis (p) very long and slender with rather thick penial sheath (ps) covering from atrium to almost middle of penis. Inner sculpture of penis with small conical penial pilasters (pp), and three prominent longitudinal folds along entire length of penis chamber. Epiphallus $(\mathrm{e} 1+\mathrm{e} 2)$ approximately half of penis length: e1 elongate and slender, and e2 very short and bulbous. Inner sculpture of e1 nearly smooth with small, thin, and longitudinal folds, and e2 densely papillate. Epiphallic caecum (ec) straight, short, and approximately as long as e2; penial retractor muscle (prm) thin and attached at tip. Flagellum (fl) small, rather short, and approximately as long as e2. Vas deferens (vd) very long, thin, and convoluted. Vagina (v) short, enlarged, thickened and cylindrical. Gametolytic sac (gs) short and bulbous; gametolytic duct (gd) long, enlarged near vagina then becoming smaller and very slender. Free oviduct (fo) long, cylindrical, and encircled with dense tissue near vagina.

RADULA (Fig. 10D). Teeth arranged in wide-angle U-shape with half row consisting of about 97-98 teeth at middle plate. Central tooth symmetrical monocuspid, elongated oblong-shaped with curved cusp, and slightly smaller than lateral tooth. Lateral and marginal teeth undifferentiated, asymmetrical monocuspid and elongated oblong-shaped with curved cusp; outermost teeth gradually becoming smaller.

\section{Distribution}

Aenigmatoconcha eunetis sp. nov. occurs in a few isolated limestone hills in Uthai Thani Province.This new species lives on limestone karsts, where snails tend to hide themselves in rock crevices and shelter during the daytime.

\section{Remarks}

Aenigmatoconcha eunetis sp. nov. clearly differs from all congeners in having 1) the longest penis, 2) penial internal sculpture consisting of longitudinal folds and small conical penial pilasters, and 3) inner sculpture of epiphallus (e2) densely papillae. For comparison, A. clivicola has oblique trapezoidshaped penial pilasters, A. mitis has oblique wrinkled penial pilasters with a longitudinal fold, and A. sumonthai has very small conical penial pilasters without longitudinal fold. In addition, for the inner sculpture of epiphallus (e2), A. clivicola has irregularly oblique trapezoid and small conical papillae. Aenigmatoconcha mitis and A. sumonthai have loose papillae arranged in oblique rows, but the former has relatively fewer rows and papillae are significantly larger in size than the latter. Moreover, radular teeth of only A. eunetis sp. nov. are arranged in wide-angle U-shaped row and oblong-shaped teeth, while radular teeth of other Aenigmatoconcha species are arranged in V-shaped rows and spatulate in shape.

\section{Discussion}

Each of the four Aenigmatoconcha species forms a well-defined clade in the COI phylogeny. Aenigmatoconcha can be divided into two groups based on the genital characters (Figs 1-2; Table 2). Group I (Fig. 2) has a long epiphallic caecum and short penial caecum, and contains one species, $A$. clivicola, which is restricted to northeasthern Thailand (Fig. 1). Group II (Fig. 2) has a short epiphallic caecum and no penial caecum; this group contains A. mitis, A. sumonthai, and A. eunetis sp. nov. 


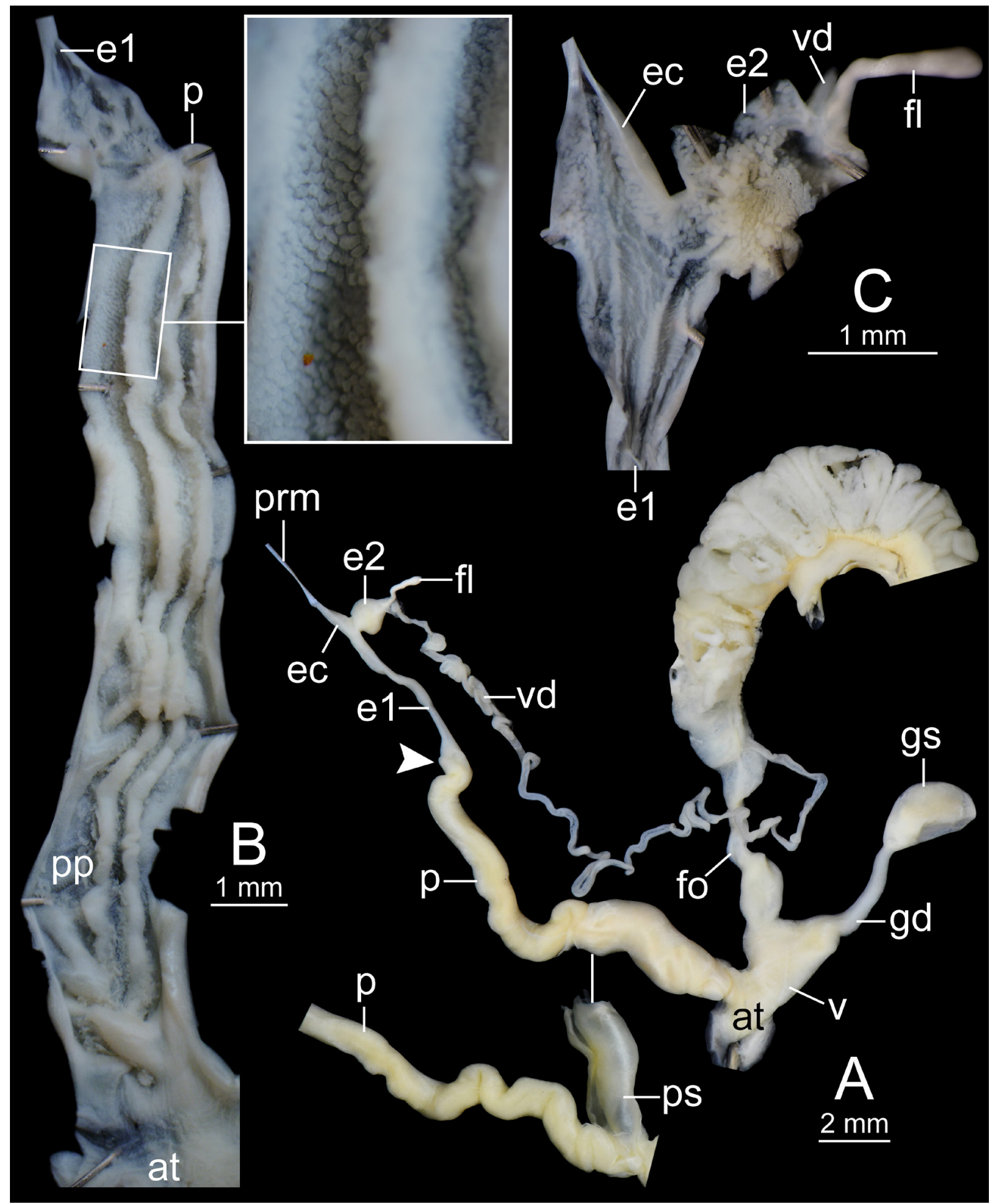

Fig. 9. Genital system of Aenigmatoconcha eunetis Pholyotha \& Panha sp. nov., paratype CUMZ 7933 from Uthai Thani Province. A. General view of genitalia. B. Internal structure of penis; inset showing penial sculpture. C. Internal structure of epiphallus and epiphallic caecum. White arrow indicates the junction between the penis and epiphallus. 
This group occurs from central to southern Thailand along the Tenasserim Range (Fig. 1). The COI tree showed very low nodal support for the relationships among the two Aenigmatoconcha groups and the other two helicarionid genera. Although the phylogenetic relationships among Aenigmatoconcha, Sophina and Chalepotaxis remain unresolved, the genital characters of both groups of Aenigmatoconcha were clearly distinct from Sophina and Chalepotaxis. In the phylogenetic tree of the $28 \mathrm{~S}$ gene, moreover, these three genera were confirmed as different genera, but the systematic position of two Aenigmatoconcha species (A. clivicola and A. sumonthai) is unresolved (Sutcharit et al. 2020a). Further research should include on more genes and more taxa of the Southeast Asian helicarionoids to better understand the phylogenetic relationships and morphological evolution of these groups.

Aenigmatoconcha can be distinguished from almost all other Southeast Asian helicarionoid genera by their unique milky to pale whitish-horny and umbilicate shell. Other helicarionoids with a whitish shell include Macrochlamys psyche Vermeulen et al., 2019, Sarika lactoconcha Pholyotha \& Panha, 2020, and Sarika consepta (Benson, 1860). However, the relatively medium to large-sized shells (shell width larger than $15 \mathrm{~mm}$ ), narrowly perforate umbilicus, genital structure, and radula with triangular teeth of these three species clearly differentiate them from all Aenigmatoconcha species (Vermeulen et al. 2019; Pholyotha et al. 2020a, 2020b). The greatest similarity in shell characters
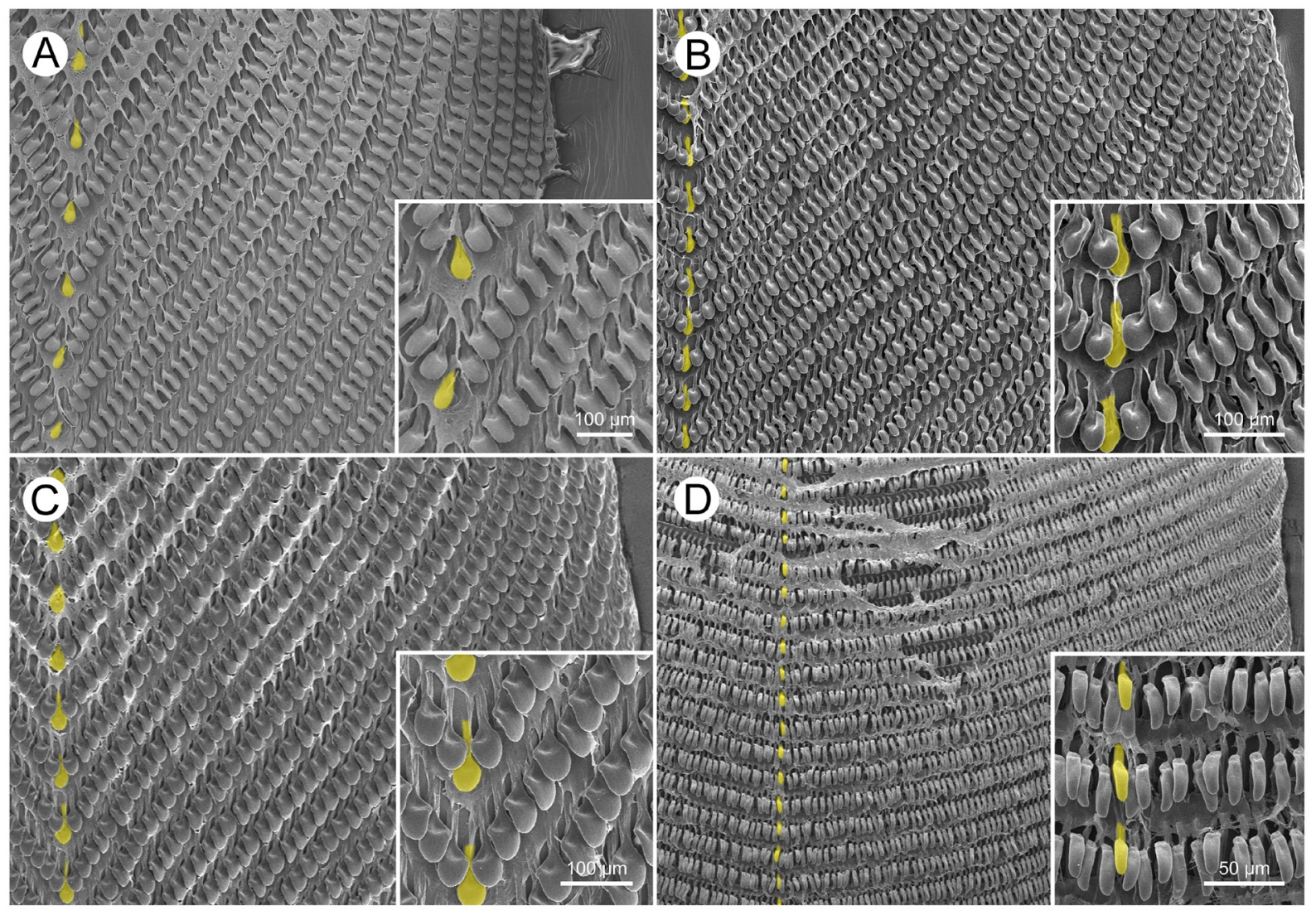

Fig. 10. Radula morphology of Aenigmatoconcha spp. A. A. clivicola Tumpeesuwan \& Tumpeesuwan, 2017, specimen CUMZ 7929 from Loei Province. B. A. mitis (Pfeiffer, 1863) comb. nov., specimen CUMZ 7687 from Kanchanaburi Province. C. A. sumonthai Tumpeesuwan \& Tumpeesuwan, 2018, specimen CUMZ 7922 from Chumphon Province. D. A. eunetis Pholyotha \& Panha sp. nov., paratype CUMZ 7933 from Uthai Thani Province. Central tooth in yellow. Scale bars: $\mathrm{A}-\mathrm{C}=100 \mu \mathrm{m} ; \mathrm{D}=50 \mu \mathrm{m}$. 
occurred in Sophina and Chalepotaxis, but their genitalia are obviously different. The distinctive characters between Aenigmatoconcha and Chalepotaxis have been reported (Tumpeesuwan \& Tumpeesuwan 2017; Sutcharit et al. 2020a). However, Tumpeesuwan and Tumpeesuwan (2017) did not report the presence of a "penial sheath" and a "flagellum" in A. clivicola (the type species). In fact, they stated that the absence of a penial sheath in Aenigmatoconcha is a diagnostic difference between Aenigmatoconcha and Chalepotaxis. Yet, in the present work, the four Aenigmatoconcha species clearly exhibited a well-developed penial sheath and flagellum. Hence, the only difference between Chalepotaxis and Aenigmatoconcha is the presence of a flagellum in the latter (Páll-Gergely et al. 2016). In addition to the genitalia without a dart apparatus, the presence of well-developed anterior and posterior left dorsal lobes is a significant character of Aenigmatoconcha, while Sophina has an undivided left dorsal lobe and a dart apparatus (Blanford \& Godwin-Austen 1908; Sutcharit et al. 2020a). However, information on the mantle lobe morphology of Chalepotaxis was not available for comparison.

Among Southeast Asian helicarionoid genera with uniform and spatulate-shaped radula, Sophina is the only genus that a dart apparatus present in genitalia, but a flagellum absent. While genitalia of Aenigmatoconcha lack dart apparatus, but contain the flagellum, and genitalia of Chalepotaxis lack both organs. Generally, some characters of genital anatomy, such as a penial caecum, penial verge, dart apparatus, or flagellum, have been hypothesized to evolve repeatedly during the evolution of land snails, and have been noticed in many groups of terrestrial pulmonate snails (Solem 1966; Hausdorf 1998; Hyman \& Ponder 2010; Hirano et al. 2014; Köhler \& Criscione 2015; Köhler et al. 2020; Sutcharit et al. 2020a). However, the classification of these three genera based on the presence or absence of the dart apparatus and flagellum is consistent with the molecular phylogeny (Sutcharit et al. 2020a).

From the East of Tenasserim Range to northeastern Thailand, three Aenigmatoconcha species occurred in a few limestone karsts, while only $A$. mitis occurs in many limestone karsts from central to western Thailand (Fig. 1). Aenigmatoconcha clivicola is confined to Loei Province, northeastern Thailand, while A. eunetis sp. nov. to Uthai Thani Province, central Thailand, and A. sumonthai to Chumphon Province, southern Thailand. The isolation explains the degree of endemism and the very high genetic divergence among sister lineages $(9.7 \%$ to $12.0 \%)$ within Aenigmatoconcha. Regarding the West of Tenasserim Range, Sophina also reveals a high degree of endemism and localization with a pattern of one outcrop for one lineage in the Salween Basin, Southern Myanmar. These phenomena can be generally observed in karst-restricted animals because a very large number of ecological niches in karst ecosystems promote their evolutionary diversification and evolution of remarkably different lifestyles (Clements et al. 2006; Foon et al. 2017; Grismer et al. 2020; Sutcharit et al. 2020a). Therefore, our discovery enhances the understanding of karst biodiversity and supplements the information on terrestrial snails in Thailand available for efforts to establish well-planned and knowledge-based conservation procedures for Thai limestone protection in the future.

\section{Acknowledgements}

We thank members of the Animal Systematics Research Unit (ASRU), Department of Biology, Faculty of Science, Chulalongkorn University, and the Plant Genetic Conservation Project under the Royal Initiative of Her Royal Highness Princess Maha Chakri Sirindhorn for their help in field collecting, suggestions and technical support. We are grateful to J. Ablett, F. Naggs and H. Taylor (NHM, London) for allowing us to examine the material housed in the type collections, the type material database, and photographs. We appreciate constructive comments from anonymous reviewers during the peer review. The work was funded by The Thailand Research Fund (TRF-DPG628001), and Center of Excellence on Biodiversity (BDC-PG4-163008) to S.P. and was supported by the Ratchadapisek Somphot Fund for Postdoctoral Fellowship, Chulalongkorn University to S.P. and A.P. 


\section{References}

American Veterinary Medical Association. 2020. AVMA Guidelines for the Euthanasia of Animals: 2020 Edition. Available from https:/www.avma.org/sites/default/files/2020-01/2020-Euthanasia-Final-1-17-20.pdf. [accessed 12 Feb 2020]

Ashburton J. 1864. Paper read at the Royal Geographical Society 10th March, 1862. In: Mouhot H. (ed.) Travels in the Central Parts of Indo-China (Siam), Cambodia, and Laos, During the Years 1858, 1859, and 1860: 296-300. Murray, London.

Baur B. 2010. Stylommatophoran Gastropods. In: Leonard J.L. \& Córdoba-Aguilar A. (eds) The Evolution of Primary Sexual Characters in Animals: 197-217. Oxford University Press, USA.

Blanford W.T. \& Godwin Austen H.H. 1908. Mollusca: Testacellidae and Zonitidae. In: Bingham C.T. (ed.) The Fauna of British India including Ceylon and Burma. Taylor and Francis, London.

Clements R., Sodhi N.S., Schilthuizen M. \& Ng P.K. 2006. Limestone karsts of Southeast Asia: Imperiled arks of biodiversity. Bioscience 56 (9): 733-742. https://doi.org/fq9mjv

Dumrongrojwattana P. \& Tanmuangpak K. 2020. The terrestrial microsnail genus Aulacospira Möllendorff, 1890 (Eupulmonata, Stylommatophora, Hypselostomatidae) in Thailand with key to Thai species. ZooKeys 980: 23-42. https://doi.org/10.3897/zookeys.980.54100

Felsenstein J. 2004. Inferring Phylogenies. Massachusetts: Sinauer Associates, Sunderland.

Fischer H. \& Dautzenberg P. 1904. Catalogue des Mollusques terrestres et fluviatiles de l'Indo-Chine orientale cités jusqu'à ce jour. Mission Pavie, Études diverses 3: 390-450.

https:/gallica.bnf.fr/ark:/12148/bpt6k8814596 [accessed 22 July 2021]

Fischer P. 1891. Catalogue et distribution géographique des Mollusques terrestres, fluviatiles \& marins d'une partie de l'Indo-Chine (Siam, Laos, Cambodge, Cochinchine, Annam, Tonkin). Imprimerie Dejussieu Père et Fils, Autun. https://doi.org/10.5962/bhl.title.14809

Folmer O., Black M., Hoeh W., Lutz R. \& Vrijenhoek R. 1994. DNA primers for amplification of mitochondrial cytochrome c oxidase subunit I from diverse metazoan invertebrates. Molecular Marine Biology and Biotechnology 3: 294-299.

Foon J.K., Clements G.R. \& Liew T.-S. 2017. Diversity and biogeography of land snails (Mollusca, Gastropoda) in the limestone hills of Perak, Peninsular Malaysia. ZooKeys 682: 1-94.

https://doi.org/10.3897/zookeys.682.12999

Gardner S., Sidisunthorn P. \& Chayamarit K. 2015. Forest Trees of Southern Thailand Volume 1 (Acanthaceae to Escalloniaceae). Kobfai Publishing Project, Bangkok.

Grismer L.L., Wood P.L., Le M.D., Quah E.S.H. \& Grismer J.L. 2020. Evolution of habitat preference in 243 species of Bent-toed geckos (Genus Cyrtodactylus Gray, 1827) with a discussion of karst habitat conservation. Ecology and Evolution 10: 13717-13730. https://doi.org/10.1002/ece3.6961

Hausdorf B. 1998. Phylogeny of the Limacoidea sensu lato (Gastropoda: Stylommatophora). Journal of Molluscan Studies 64: 35-66. https://doi.org/10.1093/mollus/64.1.35

Hillis D.M. \& Bull J.J. 1993. An empirical test of bootstrapping as a method for assessing confidence in phylogenetic analysis. Systematic Biology 42: 182-192. https://doi.org/10.1093/sysbio/42.2.182

Hirano T., Kameda Y., Kimura K. \& Chiba S. 2014. Substantial incongruence among the morphology, taxonomy, and molecular phylogeny of the land snails Aegista, Landouria, Trishoplita, and Pseudobuliminus (Pulmonata: Bradybaenidae) occurring in East Asia. Molecular Phylogenetics and Evolution 70: 171-181. https://doi.org/10.1016/j.ympev.2013.09.020 
Hirano T., Wada S., Mori H., Uchida S., Saito T. \& Chiba S. 2018. Genetic and morphometric rediscovery of an extinct land snail on oceanic islands. Journal of Molluscan Studies 84: 148-156.

https://doi.org/10.1093/mollus/eyy003

Huelsenbeck J.P. \& Rannala B. 2004. Frequentist properties of Bayesian posterior probabilities of phylogenetic trees under simple and complex substitution models. Systematic Biology 53: 904-913. https://doi.org/10.1080/10635150490522629

Hyman I.T. \& Köhler F. 2018 Reconciling comparative anatomy and mitochondrial phylogenetics in revising species limits in the Australian semislug Helicarion Férussac, 1821 (Gastropoda: Stylommatophora). Zoological Journal of the Linnean Society 184: 933-968. https://doi.org/10.1093/zoolinnean/zly017

Hyman I.T. \& Köhler F. 2019. Phylogeny and systematic revision of the helicarionid semislugs of eastern Queensland (Stylommatophora, Helicarionidae). Contributions to Zoology 88 (4): 351-451. https://doi.org/10.1163/18759866-20191416

Hyman I.T. \& Ponder W.F. 2010. A morphological phylogenetic analysis and generic revision of Australian Helicarionidae (Gastropoda: Pulmonata: Stylommatophora), and an assessment of the relationships of the family. Zootaxa 2462: 1-148. http://doi.org/10.11646/zootaxa.2462.1.1

Inkhavilay K., Sutcharit C., Bantaowong U., Chanabun R., Siriwut W., Srisonchai R., Pholyotha A., Jirapatrasilp P. \& Panha S. 2019. Annotated checklist of the terrestrial molluscs from Laos (Mollusca, Gastropoda). ZooKeys 834: 1-166. http://doi.org/10.3897/zookeys.834.28800

Köhler F. \& Criscione F. 2015. A molecular phylogeny of camaenid land snails from northwestern Australia unravels widespread homoplasy in morphological characters (Gastropoda, Helicoidea). Molecular Phylogenetics and Evolution 83: 44-55. https://doi.org/10.1016/j.ympev.2014.11.009

Köhler F., Criscione F. \& Shea M. 2020. A mitochondrial phylogeny uncovers taxonomic ambiguity and complex phylogeographic patterns in the eastern Australian land snail Austrochloritis (Stylommatophora, Camaenidae). Journal of Zoological Systematics and Evolutionary Research 58: 1005-1020.

https://doi.org/10.1111/jzs.12366

Kumar S., Stecher G. \& Tamura K. 2016. MEGA7: molecular evolutionary genetics analysis version 7.0 for bigger datasets. Molecular Biology and Evolution 33: 1870-1874.

https://oi.org/10.1093/molbev/msw054

Latinne A., Waengsothorn S., Rojanadilok P., Eiamampai K., Sribuarod K. \& Michaux J.R. 2013. Diversity and endemism of Murinae rodents in Thai limestone karsts. Systematics and Biodiversity 11: 323-344. https://doi.org/10.1080/14772000.2013.818587

Liew T.S., Schilthuizen M. \& Vermeulen J.J. 2009. Systematic revision of the genus Everettia GodwinAusten, 1891 (Mollusca: Gastropoda: Dyakiidae) in Sabah, northern Borneo. Zoological Journal of the Linnean Society 157: 515-550. https://doi.org/10.1111/j.1096-3642.2009.00526.x

Likhitrakarn N., Golovatch S.I., Jeratthitikul E., Srisonchai R., Sutcharit C. \& Panha S. 2020. A remarkable new species of the millipede genus Trachyjulus Peters, 1864 (Diplopoda, Spirostreptida, Cambalopsidae) from Thailand, based both on morphological and molecular evidence. ZooKeys 925: 55-72. https://doi.org/10.3897/zookeys.925.49953

Mauro D.S. \& Agorreta A. 2010. Molecular systematics: a synthesis of the common methods and the state of knowledge. Cellular \& Molecular Biology Letters 15: 311-341.

https://doi.org/10.2478/s11658-010-0010-8 
Miller M.A., Pfeiffer W. \& Schwartz T. 2010. Creating the CIPRES science gateway for inference of large phylogenetic trees. Proceedings of the Gateway Computing Environments Workshop (GCE), IEEE, New Orleans, Louisiana. https://doi.org/10.1109/GCE.2010.5676129

Mouhot H. 1864. Travels in the Central Parts of Indo-China (Siam), Cambodia, and Laos, During the Years 1858, 1859, and 1860. Murray, London.

Myers N., Mittermeier R.A., Mittermeier C.G., da Fonseca G.A.B. \& Kent J. 2000. Biodiversity hotspots for conservation priorities. Nature 403: 853-858. https://doi.org/10.1038/35002501

Naggs F., Panha S. \& Raheem D. 2006. Developing land snail expertise in South and Southeast Asia, a new Darwin Initiative Project. The Natural History Journal of Chulalongkorn University 6: 43-46.

Páll-Gergely B., Fehér Z., Otani J. U. \& Asami T. 2016. An integrative taxonomic approach to infer the systematic position of Chalepotaxis Ancey, 1887 (Gastropoda: Stylommatophora: Helicarionidae). Molluscan Research 37: 113-119. https://doi.org/10.1080/13235818.2016.1234996

Pauwels O.S.G., Sumontha M., Panitvong N. \& Varaguttanonda V. 2014. Cyrtodactylus khelangensis, a new cave-dwelling Bent-toed Gecko (Squamata: Gekkonidae) from Lampang Province, northern Thailand. Zootaxa 3755 (6): 584-594. https://doi.org/10.11646/zootaxa.3755.6.5

Pfeiffer L. 1863. Descriptions of thirty-six new land shells from the collection of H. Cuming, Esq. Proceedings of the Zoological Society of London 30: 268-278. [Published in parts, dates follow Duncan (1937)].

Pfeiffer L. 1868. Monographia heliceorum viventium supplementum tertium: sistens descriptiones systematicas et criticas omnium hujus familiae generum et specierum hodie cognitarum, volume quintum. F.A. Brockhaus, Lipsiae.

Pholyotha A., Sutcharit C. \& Panha S. 2018. The land snail genus Macrochlamys Gray, 1847 from Thailand, with descriptions of five new species (Pulmonata: Ariophantidae). Raffles Bulletin of Zoology 66: 763-781.

Pholyotha A., Sutcharit C., Thach P., Chhuoy S., Ngor P.B. \& Panha S. 2020a. Land snail genus Sarika Godwin-Austen, 1907 (Eupulmonata: Ariophantidae) from Cambodia, with description of three new species. European Journal of Taxonomy 674: 1-21. https://doi.org/10.5852/ejt.2020.674

Pholyotha A., Sutcharit C., Tongkerd P. \& Panha S. 2020b. Integrative taxonomic revision of the land snail genus Sarika Godwin-Austen, 1907 in Thailand, with descriptions of nine new species (Eupulmonata, Ariophantidae). ZooKeys 976: 1-100. https://doi.org/10.3897/zookeys.976.53859

Pholyotha A., Sutcharit C., Tongkerd P., Jeratthitikul E. \& Panha S. 2021. Integrative systematics reveals the new land-snail genus Taphrenalla (Eupulmonata: Ariophantidae) with a description of nine new species from Thailand. Contributions to Zoology 90(1): 21-69.

https://doi.org/10.1163/18759866-BJA10013

Rambaut A., Suchard M.A., Xie D. \& Drummond A.J. 2014. Tracer v1.6. http://tree.bio.ed.ac.uk/software/tracer/

Ridd M.F., Barber A.J. \& Crow M.J. 2011. Introduction to the geology of Thailand. In: Ridd M.F., Barber A.J. \& Crow M.J. (eds) The Geology of Thailand: 1-18. Geological Society, London.

Ronquist F., Teslenko M., van der Mark P., Ayres D.L., Darling A., Höhna S., Larget B., Liu L., Suchard M.A. \& Huelsenbeck J.P. 2012. MrBayes 3.2: Efficient Bayesian phylogenetic inference and model choice across a large model space. Systematic Biology 61: 539-542.

https://doi.org/10.1093/sysbio/sys029

Sedgwick W.C. \& Schwendinger P.J. 1990. On a new cave-dwelling Liphistius from Thailand (Araneae: Liphistiidae). Bulletin of the British Arachnological Society 8:109-112. 
Siriboon T., Sutcharit C., Naggs F., Rowson B. \& Panha S. 2014. Revision of the carnivorous snail genus Discartemon Pfeiffer, 1856, with description of twelve new species (Pulmonata, Streptaxidae). ZooKeys 401: 45-107. https://doi.org/10.3897/zookeys.401.7075

Siriboon T., Naggs F., Wade C.M., Jeratthitikul E., Tongkerd P., Jirapatrasilp P., Panha S. \& Sutcharit C. 2020. Phylogenetic relationships of the carnivorous terrestrial snail family Streptaxidae (Stylommatophora: Achatinina) in Thailand and surrounding areas of Southeast Asia. Systematics and Biodiversity 18: 720-738. https://doi.org/10.1080/14772000.2020.1783384

Solem A. 1966. Some non-marine mollusks from Thailand, with notes on classification of the Helicarionidae. Spolia Zoologica Musei Hauniensis 24: 1-110.

Srisonchai R., Enghoff H., Likhitrakarn N. \& Panha S. 2018. A revision of dragon millipedes I: genus Desmoxytes Chamberlin, 1923, with the description of eight new species (Diplopoda, Polydesmida, Paradoxosomatidae). ZooKeys 761: 1-177. https://doi.org/10.3897/zookeys.761.24214

Stamatakis A. 2014. RAxML Version 8: A tool for phylogenetic analysis and post-analysis of large phylogenies. Bioinformatics 30: 1312-1313. https://doi.org/10.1093/bioinformatics/btu033

Sumontha M., Chomngam N., Phanamphon E., Pawangkhanant P., Viriyapanon C., Thanaprayotsak W. \& Pauwels O.S.G. 2017. A new limestone-dwelling leaf-toed gecko (Gekkonidae: Dixonius) from Khao Sam Roi Yot massif, peninsular Thailand. Zootaxa 4247 (5): 556-568.

https://doi.org/10.11646/zootaxa.4247.5.2

Sutcharit C., Jeratthitikul E., Pholyotha A., Lin A. \& Panha S. 2020a. Molecular phylogeny reveals high diversity and endemism in the limestone karst-restricted land snail genus Sophina Benson, 1859 from Myanmar (Eupulmonata: Helicarionidae), with description of four new species. Journal of Zoological Systematics and Evolutionary Research 58: 957-981. https://doi.org/10.1111/jzs.12420

Sutcharit C., Jeratthitikul E., Tongkerd P. \& Panha S. 2020b. Reassessment and systematic position of the sinistral snails of genus Hemiplecta from Thailand (Eupulmonata: Ariophantidae), with description of two new species. Contributions to Zoology: 1-33. https://doi.org/10.1163/18759866-BJA10016

Sutcharit C., Thach P., Chhuoy S., Ngor P.B., Jeratthitikul E., Siriwut W., Srisonchai R., Ng T.H., Pholyotha A., Jirapatrasilp P. \& Panha S. 2020c. Annotated checklist of the land snail fauna from southern Cambodia (Mollusca, Gastropoda). ZooKeys 948: 1-46. https://doi.org/10.3897/zookeys.948.51671

Tanabe A.S. 2011. Kakusan4 and Aminosan: two programs for comparing nonpartitioned, proportional and separate models for combined molecular phylogenetic analyses of multilocus sequence data. Molecular Ecology Resources 11: 914-921. https://doi.org/10.1111/j.1755-0998.2011.03021.x

Tompa A.S. 1984. Land snails (Stylommatophora). In: Tompa A.S. \& Verdonk N.H. (eds) The Mollusca, Vol. 7: Reproduction: 47-140. Academic Press, London.

Tongkerd P., Lee T., Panha S., Burch J.B. \& O’Foighil D. 2004. Molecular phylogeny of certain Thai gastrocoptine micro land snails (Stylommatophora: Pupillidae) inferred from mitochondrial and nuclear ribosomal DNA sequences. Journal of Molluscan Studies 70: 139-147.

https://doi.org/10.1093/mollus/70.2.139

Tryon Jr. G.W. 1886. Manual of Conchology; Structural and Systematic. With illustrations of the species. Second Series: Pulmonata. Volume II. Zonitidae. Academy of Natural Sciences, Philadelphia.

Tumpeesuwan C. \& Tumpeesuwan S. 2017. Discovery of an overlooked helicarionid land snail (Helicarionidae: Durgellinae) from northeastern Thailand, with description of a new genus and new species, and a note on radula morphology and genital system. Raffles Bulletin of Zoology 65: 174-181. 
Tumpeesuwan C. \& Tumpeesuwan S. 2018. Aenigmatoconcha sumonthai, a new helicarionid land snail from Chumphon Province, Southern Thailand (Helicarionidae: Durgellinae). Raffles Bulletin of Zoology 66: 170-176. http://doi.org/10.5281/zenodo.4504598

Vermeulen J.J., Luu H.T., Theary K. \& Anker K. 2019. New species of land snails (Mollusca: Gastropoda: Caenogastropoda and Pulmonata) of the Mekong Delta Limestone Hills (Cambodia, Vietnam). Folia Malacologica 27: 7-41. https://doi.org/10.12657/folmal.027.001

Zhang L.-J., Zhu Y.-J. \& Lyu Z.-T. 2020. A new sinistral species of the land-snail genus Satsuma (Pulmonata: Camaenidae) from China. Molluscan Research 40 (1): 93-100.

https://doi.org/10.1080/13235818.2019.1644721

Manuscript received: 26 january 2021

Manuscript accepted: 18 May 2021

Published on: 10 September 2021

Topic editor: Rudy Joqué

Section editor: Thierry Backeljau

Desk editor: Fariza Sissi

Printed versions of all papers are also deposited in the libraries of the institutes that are members of the EJT consortium: Muséum national d'histoire naturelle, Paris, France; Meise Botanic Garden, Belgium; Royal Museum for Central Africa, Tervuren, Belgium; Royal Belgian Institute of Natural Sciences, Brussels, Belgium; Natural History Museum of Denmark, Copenhagen, Denmark; Naturalis Biodiversity Center, Leiden, the Netherlands; Museo Nacional de Ciencias Naturales-CSIC, Madrid, Spain; Real Jardín Botánico de Madrid CSIC, Spain; Zoological Research Museum Alexander Koenig, Bonn, Germany; National Museum, Prague, Czech Republic. 